\title{
Unconventional Monetary Policy and Risk-Taking: Evidence from Agency Mortgage REITs
}

\author{
W. Scott Frame and Eva Steiner
}

\section{Working Paper 2018-8 \\ August 2018}

\begin{abstract}
We study how the Federal Reserve's quantitative easing (QE) influenced the behavior of Agency mortgage real estate investment trusts (REITs)-a set of institutions identified by the Financial Stability Oversight Council as posing systemic risk. We document that Agency mortgage REITs: [i] equity prices reacted to $\mathrm{QE}$ announcements and in a manner consistent with their business prospects; [ii] grew markedly during QE2 and receded during QE3 in relation to the Federal Reserve's Agency MBS purchase activity; and [iii] increased their leverage during QE3. Our findings are consistent with unconventional monetary policy actions crowding out private investment and "reaching for yield" behavior by financial institutions.
\end{abstract}

JEL classification: E58, G21, G23, G28

Key words: quantitative easing, risk-taking, REITs, GSEs, mortgages, securitization

https://doi.org/10.29338/wp2018-08

This paper has benefited from comments by Jose Berrospide, Yongheng Deng, Aurel Hizmo, Arito Ono, Rodney Ramcharan, Philip Swagel, Joe Tracy, John Worth, and seminar participants at the Federal Reserve Board, Louisiana State Uuniversity, the 2018 Midwest Finance Association Meeting, the 2018 ASSA annual meeting, the 2017 ARUEA national conference, and the 2017 "Unconventional Monetary Policy: Lessons Learned" conference held at the Hong Kong Monetary Authority. The authors thank Abhijeet Bhalkikar, Manny Dong, and Pam Frisbee for outstanding research assistance and Ellen Correia Golay and Brett Rose for providing the Federal Reserve data on purchases and holdings of U.S. Treasuries and Agency MBS. The views expressed here are the authors' and not necessarily those of the Federal Reserve Bank of Atlanta or the Federal Reserve System. Any remaining errors are the authors' responsibility.

Please address questions regarding content to W. Scott Frame, Research Department, Federal Reserve Bank of Atlanta, 1000 Peachtree Street NE, Atlanta, GA 30309-4470, 404-498-8783, scott.frame@atl.frb.org, or Eva Steiner, Cornell SC Johnson College of Business, 465B Statler Hall, Ithaca, NY 14853, 607-255-6697, ems457@cornell.edu.

Federal Reserve Bank of Atlanta working papers, including revised versions, are available on the Atlanta Fed's website at frbatlanta.org. Click "Publications" and then "Working Papers." To receive e-mail notifications about new papers, use frbatlanta.org/forms/subscribe. 


\section{Introduction}

Following the recent global financial crisis and into the Great Recession, the Federal Reserve reduced its overnight interest rate (effectively) to the zero lower bound and engaged in large-scale purchases of long-term U.S. Treasury and Federal Agency securities. From the start of 2008 through the end of 2017, the U.S. central banks' balance sheet grew from $\$ 0.9$ trillion to $\$ 4.5$ trillion, and is now principally comprised of longer-term U.S. Treasury notes and bonds ( $\$ 2.5$ trillion) and Federal Agency mortgage-backed securities ( $\$ 1.8$ trillion). ${ }^{1}$ Recently, the Federal Reserve's Federal Open Market Committee (FOMC) has started to raise the short-term policy rate and announced a balance sheet normalization plan that intends to slowly and predictably reduce the central banks' portfolio via run-off. ${ }^{2}$ While the long-run size and composition of the central banks' balance sheet remain open policy questions, one important consideration will be the adjustment of the $\$ 5.8$ trillion Federal Agency mortgage-backed securities (Agency MBS) market since the central bank now holds almost 29 percent of the outstanding bonds.

A number of recent empirical studies have demonstrated that the Federal Reserve's large-scale asset purchases, or "quantitative easing" (QE), lowered long-term interest rates as intended - both for U.S. Treasury securities and Agency MBS. ${ }^{3}$ As a matter of economic theory, these policy-driven effects are believed to result from reduced term premiums and/or lower expected levels of future short-term interest rates. The term premium may fall as central bank large-scale asset purchases reduce the amount of long-term, low-risk bonds in private-sector portfolios - a mechanism generally referred to as the "portfolio balance channel" (e.g., Bernanke, 2010). The announcement of asset purchases may also cause market participants to revise down their expectations about the future path of short-term interest rates - known as the "signaling channel" (e.g.,

${ }^{1}$ Data as of December 27, 2017. Federal Reserve balance sheet information is available weekly from Federal Reserve Statistical release (H.4.1. Factors Affecting Reserve Balances) available at: https://www.federalreserve.gov/releases/h41/.

2 The June 2017 Addendum to the FOMC's Policy Normalization Principles and Plans is available at: https://www.federalreserve.gov/newsevents/pressreleases/monetary20170614c.htm. At its September 2017 meeting, the FOMC voted to implement this program starting in October.

3 See Gagnon, Raskin, Remache, and Sack (2011); Krishnamurthy and Vissing-Jorgensen (2011); Hancock and Passmore (2011); Hamilton and Wu (2012); Neely (2012); D’Amico and King (2013); and Bauer and Rudebusch (2014). 
Bauer and Rudebusch, 2014). Central bank communication that interest rates will remain low for a considerable period of time likely amplify these effects.

Such monetary policy interventions can have important implications for financial institutions. For example, Chodorow-Reich (2014) finds that the initial round of the Federal Reserve's quantitative easing (QE1) benefitted various types of institutions by increasing legacy asset values and raising their net worth. However, as U.S. monetary policy accommodation lingered, there was growing concern about the potential for financial stability risks to emerge. Bernanke (2013) notes that maintaining low interest rates for too long may create incentives for market participants to take on greater duration or credit risks, or to employ additional financial leverage, in an effort to "reach for yield." While such risk-taking behavior is seemingly an intended consequence of $\mathrm{QE}$, some recent theoretical research points to it being potentially distorted by agency problems associated with delegated asset management (e.g., Rajan 2005; Feroli, Kashyap, Schoenholtz, and Shin 2014; Acharya and Naqvi 2015; Morris and Shin 2016). Specifically, very low interest rate environments may make asset managers more sensitive to a funds' performance relative to peers, inducing them to take-on more risk. Related empirical evidence is provided by Chodorow-Reich (2014), DiMaggio and Kacperczyk (2014), and Choi and Kronlund (2018), each of whom finds evidence of heightened risk-taking by different types of non-bank financial institutions since the Federal Reserve began QE. ${ }^{4}$

This paper examines a set of financial institutions that grew markedly during the Federal Reserve's balance sheet expansion: Agency Mortgage REITs (Agency MREITs). During the first two rounds of quantitative easing (QE1 and QE2), Agency MREIT total assets grew from $\$ 79.2$ billion to $\$ 363.5$ billion (356 percent) before receding during QE3. As the moniker suggests, Agency MREITs hold mortgage-backed securities guaranteed by U.S. government agencies (Fannie Mae, Freddie Mac, and Ginnie Mae) and finance them with a

\footnotetext{
${ }^{4}$ This research is part of a new (and broader) literature describing the existence of a "risk taking channel" of monetary policy; one that is distinct from the familiar interest rate and credit channels (e.g., Adrian and Shin, 2010; Borio and Zhu, 2012). Empirical analysis of bank behavior suggests that they make ex ante riskier loans as monetary policy becomes more accommodative - and that this effect that is stronger for better capitalized banks (Jimenez, Ongena, Peydro, and Saurina, 2014; Ioannidou, Ongena, and Peydro, 2015; Dell'Ariccia, Leaven, and Suarez, 2017). Related research finds that accommodative monetary policy is associated with tighter yield spreads for U.S. corporate loans - particularly for the riskiest borrowers (Delis, Hasan, and Mylolonidis, 2017; Paligorova and Santos, 2017).
} 
combination of equity and short-term debt in the form of repurchase agreements (repo). Hence, they are engaged in significant maturity transformation (i.e., a "carry trade") that involves material interest rate and liquidity risks without access to government backstops. In fact, the U.S. Financial Stability Oversight Council (2013) raised the specter of financial stability concerns emanating from Agency MREITs. The Council's thesis is that these institutions are vulnerable to a sharp increase in interest rates that would erode the value of their assets. Given Agency MREITs' reliance on short-term collateralized borrowing, this could lead to dealer margin calls, increases in repo haircuts, and deleveraging. At worst, dealer funding could be markedly reduced, forcing significant asset sales and placing downward pressure on Agency MBS prices (or equivalently upward pressure on yields). The underlying assumption is that Agency MREITs act in unison in response to a shock given their homogenous business model. ${ }^{5}$

To identify the effects of unconventional monetary policy on Agency MREIT growth and risk taking, we compare them with all other MREITs. These latter firms make a natural control group since they are subject to all of the same legal requirements, but typically hold a broader portfolio of mortgage-related debt. Thus we expect Non-Agency MREITs to be significantly less sensitive to the central banks' posture in the Agency MBS market than the more specialized Agency MREITs. Our empirical approach is similar to that in a recent study by Chakraborty, Goldstein and MacKinlay (2017) that examines responses to QE across U.S. commercial banks with differential exposure to the Agency MBS market.

We conduct three sets of analyses to better understand the behavior of Agency MREITs after the recent financial crisis and in the context of the Federal Reserve's QE. First, following Chodorow-Reich (2014), we conduct a high-frequency event study of the equity market reactions across Agency and Non-Agency MREITs to various central bank announcements. We find that Agency MREITs reacted to most announcements, did so in a manner consistent with their business prospects, and differently from Non-Agency MREITs, other financial institutions, as well as the broader market. Second, we study Agency MREIT asset growth and equity issuance and find that this was generally inversely associated with the Federal Reserve's Agency MBS purchase

\footnotetext{
5 This thesis rests on the fact that an important part of the financial crisis narrative concerns the liquidity risks posed
} by shadow banks that principally finance themselves using repurchase agreements (e.g., Gorton and Metrick, 2012). 
activity during QE2 and QE3. We regard this as novel evidence for the central bank directly crowding-out private investment as per the portfolio balance channel. Our third analysis focuses on the relationship between Agency MREIT risk-taking and QE. Here we find that, during QE3, Agency MREITs increased their leverage in relation to the Federal Reserve's purchase activity -- consistent with "reaching for yield" by these institutions. However, the interest rate risk profiles of these institutions became more conservative during the Tapering period, by holding more floating rate securities, lengthening liabilities, and increasing hedging.

Our analysis is most closely related to three recent papers. First, Chodorow-Reich (2014) conducts a high frequency event study of various QE announcements and the market reactions for a sample of commercial banks and life insurers (as well as the broader market). The author also provides some evidence that money market and pension funds increased their risk-taking during 2009-2011. Second, DiMaggio and Kacperczyk (2016) find that, when the Federal Reserve holds the policy rate at the effective zero lower bound, money market funds increased their risk as measured by: yield spreads, the fraction of bank-issued obligations held, asset concentration, and weighted-average maturity. Finally, Choi and Kronlund (2018) study corporate bond mutual funds and find that "reaching for yield" behavior is more pronounced when the level and slope of the term structure are low.

Our study contributes to the literature along at least two dimensions. First, to our knowledge, this is the first empirical analysis of Agency MREITs. ${ }^{6}$ This is potentially very important given the prominent role that these shadow banks could play going forward in the $\$ 5.8$ trillion Agency MBS market following the postconservatorship shrinkage of such holdings by Fannie Mae and Freddie Mac and the Federal Reserve's balance sheet normalization. Second, given that Agency MREITs do not take-on much credit risk, we are able to focus on whether these institutions altered instead their leverage, liquidity risk, and interest rate risk profiles during QE. This inquiry is in sharp contrast to the extant literature, which has focused exclusively on credit risk-taking by money market funds, pension funds, and corporate bond funds.

\footnotetext{
${ }^{6}$ Pellerin, Sabol, and Walter (2013) provide a descriptive overview of these institutions.
} 


\section{Mortgage REITs}

Real estate investment trusts (REITs) are specialized investment vehicles that invest in real estate-related assets. REITs are exempt from specific provisions of the Investment Company Act, which implies that they are not subject to prudential regulation, including leverage limits. A REIT may be a public company registered with the U.S. Securities and Exchange Commission or privately held. A public REIT may have its shares listed on an exchange, or be unlisted and have shares sold directly to investors by broker-dealers. As long as REITs distribute at least 90 percent of their taxable net income annually, they are exempt from federal corporate income tax. ${ }^{7}$ To the extent that such distributions are in the form of dividends, these profits are taxed at the shareholder's ordinary income tax rate and hence avoid double-taxation. The high level of mandatory dividend distributions implies that REITs primarily fund growth by raising new equity, rather than through retained earnings.

REITs generally specialize in either owning real estate assets or providing debt financing for them. Equity REITs own properties and typically focus on specific geographies and/or sectors (e.g., apartment, retail, or office). By contrast, mortgage REITs invest in whole mortgage loans and/or mortgage-backed securities that are secured by residential and commercial properties. As shown in Figure 1, based on the Federal Reserve's Flow of Funds data, a large share of MREIT investment is in Agency MBS guaranteed by either Fannie Mae, Freddie Mac, or Ginnie Mae. ${ }^{8}$ While Agency MBS are viewed as having virtually no credit risk, these instruments

${ }^{7}$ Other important limits placed on REITs include: [1] maintaining at least 75 percent of total assets in qualifying real estate assets and cash; [2] receiving at least 75 percent of income from some combination of rent from real property, interest from mortgages securing real property, gains from the sale of real property, and distributions from other REITs; [3] receiving at least 95 percent of its income from the aforementioned qualified real estate sources or from certain other passive sources; [4] deriving less than 30 percent of gross income from the sale or other disposition of stock or securities held for less than six months, and real property held for less than four years; and [5] issue transferrable shares held by at least 100 individuals with no five or fewer owning more than 50 percent during the last half of the taxable year.

${ }^{8}$ Fannie Mae and Freddie Mac are U.S. government-sponsored enterprises (GSEs) that securitize "conforming" residential mortgages; and since the financial crisis the two institution have enjoyed "effective" federal backing of all obligations (e.g., Frame, Fuster, Tracy, and Vickery, 2015). Ginnie Mae is a government agency within the U.S. Department of Housing and Urban Development (HUD) created exclusively to securitize government-insured mortgages. All three institutions provide blanket guarantees on their MBS in exchange for guarantee fees (insurance premiums) from mortgage originators. 
are very long-term and subject to significant prepayment risk arising from both borrower refinancing due to changes in interest rates and routine housing turnover.

[Figure 1 about here.]

Using institution-level data from S\&P Global (formerly SNL Financial), Figure 2 (Panel A) shows that MREIT investment in Agency MBS has been persistently concentrated in a subset of these institutions that specialize in managing such portfolios. These so-called Agency MREITs are typically identified as holding more than one-half of their total assets in Agency MBS on average over the life of the firm; with an actual portfolio share of about 90 percent. During the early-2000s, there were only three Agency MREITs of note (Annaly Capital Management, Anworth Mortgage Asset Corporation and Capstead Mortgage Corporation). However, following the onset of the financial crisis and the Great Recession, as many as 14 were in operation at a given point in time. Figure 2 (Panel B) presents the quarterly number of Agency and Non-Agency MREITs based on the standard definition and using the S\&P Global Financial data.

[Figure 2 about here.]

MREIT financing of Agency MBS involves a mix of equity and short-term collateralized debt in the form of bilateral repurchase agreements, or repo, entered into with broker-dealers. ${ }^{9}$ While MREITs face no regulatory leverage limits, repo haircuts place an effective limit. Further, this margin must be maintained throughout the life of the loan; a margin call will occur if the collateral value falls beyond a pre-specified amount. MREITs typically hold some unencumbered assets (cash and securities) as a liquidity buffer to cover any margin calls.

Figure 3 illustrates the aggregate capital structure of Agency MREITs (Panel A) versus Non-Agency MREITs (Panel B) using the S\&P Global data. Agency MREITs collectively averaged about eight percent equity prior to the financial crisis, but this amount subsequently increased and more recently hovers around 12-15

${ }^{9}$ Repurchase agreements are effectively collateralized loans whereby a borrower sells an asset to a lender with a promise to repurchase the asset back at a later date for a pre-specified price. Since 2005, repurchase agreements collateralized by Agency MBS have been treated as "qualified financial contracts" for the purposes of the U.S. Bankruptcy Code, meaning that they are exempt from automatic stay provision. 
percent. The figure also demonstrates that repurchase agreements are the dominant form of Agency MREIT debt financing - accounting for about 80 percent of total assets since the early 2000s. Roughly one-half of this repo debt is very short-term ( $<30$ days). The capital structure of Non-Agency MREITs is very different. Their share of equity financing steadily declined prior to the financial crisis (from roughly 20 percent to 10 percent), before jumping markedly thereafter. Non-Agency MREITs rely on repo financing much less than their Agency counterparts.

[Figure 3 about here.]

Figure 4 presents quarterly data on MREIT Agency MBS holdings in terms of both dollar levels and market shares for Agency MREITs and Non-Agency MREITs, respectively. Here we see that Agency MREITs expanded dramatically after the onset of the financial crisis and increasingly became important Agency MBS investors. Between 2008:Q4 and 2012:Q3, Agency MREITs increased their holdings of Agency MBS from $\$ 76.2$ to $\$ 337.6$ billion; and thereby increased their share of this market by more than a factor of four, from $1.5 \%$ to $6.4 \%$. These amounts and shares declined thereafter. The collective holdings of Non-Agency MREITs never rose above $\$ 50$ billion, which corresponds to less than one percent of the Agency MBS market.

[Figure 4 about here]

Much of this increase in Agency MREIT market share was concurrent with the shrinkage of Agency MBS holdings by Fannie Mae and Freddie Mac, which themselves had long been the largest investors in this market. The Federal Reserve's unconventional monetary policy, which started in 2009, interjected the central bank into the Agency MBS market, where it quickly became the largest investor. Figure 5 (Panel A) presents the Agency MBS purchases by the Federal Reserve and Fannie Mae/Freddie Mac between 2008 and 2015 as a share of newly issued securities. The Federal Reserve absorbed an amount equal to 86 percent of new issuance during 2009:Q1 (the start of QE1 purchases), before halting purchases one year later. The central bank renewed purchases of Agency MBS during 2011:Q4 (the start of QE3), although this amount steadily declined during the Tapering period. Panel B in Figure 5 shows the share of Agency MBS outstanding held by the Federal Reserve, as well as by Fannie Mae and Freddie Mac. Over the 2008 to 2015 period, the central bank increased 
its share from zero to over 30 percent and the GSEs' share of Agency MBS investment declined from about 16 percent to four percent.

[Figure 5 about here.]

Given that REITs must distribute at least 90 percent of their taxable net income annually to remain exempt from federal corporate income tax, any significant growth requires new equity issuance. Figure 6 presents equity issuance data for Agency MREITs (Panel A) and Non-Agency MREITs (Panel B). For Agency MREITs, much of the new equity issuance is clustered in the 2010-2012 period, which coincides with the asset growth presented above.

[Figure 6 about here.]

The remarkable growth of Agency MREITs after the financial crisis, coupled with their potentially fragile business model, caught the attention of the newly created Financial Stability Oversight Council in 2013. Policymakers were concerned about the vulnerability of these shadow banks to sharp increases in interest rates that would erode the value of their assets, potentially resulting in a run on their short-term liabilities and a largescale sell-off in the Agency MBS market. Despite these conjectures, a systematic empirical analysis of Agency MREIT growth and risk-taking in the context of the Federal Reserve's quantitative easing is absent from the literature. This issue may be of ongoing policy interest as the central bank exits the Agency MBS market under its "portfolio normalization plan." Moreover, the recent experience suggests that Agency MREITs could play a significant role in the Agency MBS market going forward given the post-conservatorship shrinkage of such holdings by Fannie Mae and Freddie Mac.

\section{Event Study}

We begin our empirical analysis by conducting a high-frequency event study of the equity market reactions by (Agency and Non-Agency) MREITs to the 14 QE announcements previously studied by Chodorow-Reich (2014). This analysis has two goals. The first is to illustrate that market participants expected MREITs to be materially affected by the Federal Reserve's QE, and that MREIT equity prices reacted appropriately to the 
information available as well as compared to other financial institutions and the broader market. The second goal is to document the similarities and differences in the reactions across Agency and Non-Agency MREITs, which we use as control group in our subsequent analysis of Agency MREIT growth and risk-taking.

Central bank asset purchases tend to reduce long-term interest rates and increase the value of fixed-income securities held by institutions. In principle, we expect this effect to benefit both types of MREITs. However, Agency MBS benefit less from declines in long-term interest rates because of negative convexity owing to higher expected fixed-rate mortgage prepayments in a lower interest rate environment. Moreover, the Federal Reserve's purchase activity in the Agency MBS market directly alters investment opportunities for Agency MREITs -- a strong form of the QE “portfolio balance channel.” Thus, we expect both types of MREITs to be sensitive to QE-related announcements but we expect that Agency MREITs react differently from NonAgency MREITs, which have more diverse portfolios.

Following Chodorow-Reich (2014), we obtain high-frequency, tick-by-tick equity price data from TAQ to construct 5-minute average trading prices from 7 to 2 minutes before the monetary policy announcements to 18 to 23 minutes after. The rationale behind the high-frequency event study is to identify a causal relationship between monetary policy surprises and equity market movements in a manner that trades off the need for a narrow enough window such that other aggregate shocks are not influencing asset prices, but one long enough such that the market can plausibly digest the new information.

Table 1 presents our results for both types of MREITs and also reproduces results for life insurance companies, commercial banks, and the broader market from Chodorow-Reich (2014, Table 2). As expected, both types of MREITs reacted to most of the identified QE announcements; and there were significant differences in the reactions across Agency and Non-Agency MREITs. During QE1 and QE2, Agency MREITs generally reacted positively and in-line with the broader market, although the reaction was muted relative to Non-Agency MREITs, life insurers, and banks. This is consistent with QE increasing legacy asset values, but with fixed-rate Agency MBS capturing less than the full benefit due to negative convexity. The two forward guidance announcements that occurred during QE2 were perceived much more positively for Agency MREITs 
than for other financial institutions. This is likely due to a perception that the cost of their short-term repo liabilities would remain low for a considerable period of time. Agency MREITs reacted more strongly (in absolute terms) than Non-Agency MREITs and other financial institutions to the QE3 announcements. The announcements in May and June of 2013 were related to the so-called 'Taper Tantrum' and were quite negative for Agency MREITs as they would have unanchored expectations about their funding costs which had previously been tied-down by the forward guidance. However, this reversed with the September Federal Open Market Committee statement indicating that the economy was too soft to initiate tapering.

[Table 1 about here.]

This event study serves as the background to our main empirical analysis to follow. The results suggest that: (i) market participants clearly expected MREITs to be affected by the unconventional monetary policy measures; and (ii) that there are sufficient similarities but also important differences in the equity market reactions across Agency and Non-Agency MREITs to these announcements. We conclude from this analysis that there is some causal impact from the Federal Reserve's QE on MREITs, and that Non-Agency MREITs provide a suitable control group for our analysis of Agency MREITs.

\section{$4 \quad$ Data and Sample Selection}

Our main analysis focuses on MREIT growth and risk-taking during the Federal Reserve's QE. The primary data used for this analysis comes from S\&P Global (formerly SNL Financial) and includes detailed quarterly information about REIT balance sheets, income statements, and capital market activities. SNL lists 60 MREITs operating over the period 2005:Q1 to 2015:Q4.

For each MREIT, we collect the following quarterly balance sheet information: Total Assets, Total Agency MBS, Total Repo Debt (with sub-categories reflecting different maturities), and Total Equity. We further obtain quarterly information about whether an MREIT issued equity or repurchased shares in a particular quarter, and the amount issued or number of shares repurchased. Finally, we hand-collect data on the type of Agency MBS holdings (fixed-rate versus variable rate) and derivative positions from MREIT 10-K and 10-Q reports. As these are not required reporting items, this information is only available for a sub-set of institutions. To 
distinguish Agency MREITs, we first calculate the ratio of Agency MBS to total assets for each firm-quarter 2005:Q1 through 2015:Q4 and flag the institutions for which this ratio on average exceeds 50 percent. ${ }^{10}$

We also collect data for three interest rate variables which comprise the principal drivers of the profitability of Agency MBS investment. The 3-month and 10-year Treasury constant maturity rates come from the Federal Reserve Bank of St. Louis from which we construct measures of the level (3-month CMT) and slope of the U.S. Treasury yield curve (10-year CMT less 3-month CMT). The option-adjusted mortgage spread (OAS) is important as a measure of the "attractiveness" of Agency MBS investment versus holding long-term Treasury bonds. ${ }^{11}$ We use Bloomberg Barclay's US MBS Fixed Rate Average OAS as a proxy. ${ }^{12}$ We also collect two series that are primarily related to credit-sensitive mortgage investments held by Non-Agency MREITs. The first is the quarterly growth rate in the S\&P/Case-Shiller Home Price Index and the second is the quarterly spread between Moody's Seasoned Baa Corporate Bond yield and the yield on the 10-Year CMT.

We are interested in learning about changes in the behavior of Agency MREITs during the late-2000s, and the extent to which their behavior responded to changes in the monetary policy environment. To this end, Table 2 provides a comprehensive timeline of the Federal Reserve's unconventional monetary policy actions starting after the failure of Lehman Brothers in the fall of 2008 based on the published minutes from the Federal Open Market Committee meetings. The first round of quantitative easing (QE1) was announced in 2008:Q4 and ran through 2010:Q1. It included the purchase of $\$ 1.25$ trillion in Agency MBS, $\$ 300$ billion of U.S. Treasury securities, and \$200 billion of Agency debt. QE2 was a short-lived program (2010:Q4 - 2011:Q2) that involved the central bank purchasing an additional $\$ 600$ billion in U.S. Treasury securities but no more Agency MBS. This was followed by the Maturity Extension Program (2011:Q3 - 2012:Q4) that included the purchase

${ }^{10}$ Our results are robust to defining Agency MREITs as those whose share of Agency MBS consistently exceeds 50 percent.

11 The mortgages underlying the Agency MBS all include embedded continuous prepayment option, whose value increases in the volatility of mortgage rates. The OAS measures the yield spread of the MBS after adjusting for the value of this option.

12 Ideally, one would want to know the holdings of each institution at each point in time and collect the related OAS in order to build-up an institution-specific portfolio OAS. Unfortunately, such information is not available because MREITs do not file form 13-f. 
of another $\$ 400$ billion in very long-term U.S. Treasury securities (6-30 years) and the sale of similar short-term securities in an effort to "twist" the yield curve. During this period, the Federal Reserve began ratcheting-up its use of "forward guidance" to anchor expectations of the very short-term policy rate at the effective zero lower bound for up to two years out. QE3 (2012:Q3-2013:Q4) saw a renewal of Federal Reserve purchases of Agency MBS and the continuation of long-term U.S. Treasury purchases. During the Tapering regime (2013:Q42014:Q3), the Federal Reserve continued but gradually slowed the pace of long-term asset purchases.

[Table 2 about here.]

To supplement the information about the QE regimes, we obtain quarterly data from the Federal Reserve Bank of New York about the central banks' purchases and holdings of Agency MBS, as well as the total amount of these securities issued and outstanding per quarter.

Table 3 presents descriptive statistics for our final Agency and Non-Agency MREIT samples over the 2005-2015 timeframe. ${ }^{13}$ We have 1,002 firm observations from 15 Agency MREITs and 35 Non-Agency MREITs. On average, Agency MREITs were substantially larger than other MREITs during this period $(\$ 18.0$ billion versus $\$ 4.3$ billion). Agency MBS accounted for 84 percent of Agency MREIT assets, as compared to six percent for all other MREITs. Consistent with the growth documented above, 26 percent of Agency MREIT firm-quarters include equity issues, with the average amount issued per quarter being 1.1 percent of the total book value of assets at the beginning of the quarter. For Non-Agency MREITs, these numbers were 14 percent and 1.7 percent respectively. The average equity-to-assets ratio is also quite different between the two types of MREITs: 14 percent for Agency MREITs and 29 percent for Non-Agency MREITs over the study period. For Agency MREITs, the average ratio of total repo debt to total assets is 78 percent; with the average share of short-term repo debt (due within 30 days) being 47 percent. Non-Agency MREITs also utilize repo debt, although their average share is 16 percent. Non-Agency MREITs also maintain higher cash buffers, on average.

${ }^{13}$ We start in 2005 due to some data limitations, but lose little as there were only three Agency MREITs previously operating. 
As noted above, we have data on the types of Agency MBS held (fixed-rate versus variable rate) and use of interest rate swaps and swaptions for a subset of MREITs. We were able to obtain information on the type of Agency MBS held for 26 firms and data on derivative usage for 25 firms. Agency MREITs tend to hold mostly fixed-rate Agency MBS (58 percent), although there is very wide dispersion ( 0 to 100 percent of total Agency MBS holdings). By contrast, Non-Agency MREITs predominantly invest in variable rate Agency MBS (as the fixed-rate share is only nine percent). For Agency MREITs, the average share of swaps to total liabilities was 47 percent; adding in swaptions increases this figure to 48 percent. Non-Agency MREITs use interest rate derivatives much less intensively as the ratio of swaps to total liabilities was 14 percent - a figure invariant to the inclusion of swaptions. For both types of MREITs, there is significant cross-sectional variation in the use of interest rate derivatives.

The average 3-month constant maturity Treasury rate for our firm-quarter sample was just over one percent, but ranged from 0.01 to 5.08 percent. In terms of other variables capturing the interest rate environment, the slope of the term structure averaged two percent and the option-adjusted mortgage spread averaged 0.49 percent. The Federal Reserve's quarterly average share of Agency MBS purchases to newly issued securities was 25 percent, but ranged from zero to 86 percent.

[Table 3 about here.]

\section{QE and Agency MREIT Growth}

To identify the effects of unconventional monetary policy on Agency MREIT asset growth we compare them with all other MREITs. As noted above, these latter firms make a natural control group since they are subject to all of the same legal requirements, but typically hold a broader portfolio of mortgage-related debt. Our approach is consistent with that taken by Chakraborty, Goldstein and MacKinlay (2017), who examine differences in commercial bank responses to quantitative easing by comparing institutions with high Agency MBS holding shares to those with low ones. 


\subsection{Empirical Approach}

We begin our regression analysis by seeking to understand the drivers of Agency MREIT growth, defined as the quarterly percentage change in the book value of assets, relative to non-Agency MREITs. To identify this effect, we include a dummy variable indicating if the firm is an Agency MREIT. ${ }^{14}$

The profitability of Agency MBS investment is predicated on the level and slope of the term structure and the relative attractiveness of Agency MBS versus Treasury bonds. To capture this, we include three variables. First, we have the 3-month constant maturity Treasury rate (3-Month CMT). The second is the slope of the term structure of U.S. Treasury rates (Term Structure) defined as the difference between the 10-year and 3month constant maturity rates. We also include the option-adjusted mortgage spread (Option Adjusted Spread). Finally, we control for variation in house price growth (Case-Shiller Index) and credit risk premiums (Credit Spread).

Next, we consider a set of relevant firm characteristics. Given that REITs must distribute a large fraction of their earnings as dividends, asset growth must largely be financed through new equity issuance. We examine this by including the amount of equity issued as a percentage of total assets at the end of the previous quarter (Amount of Equity Issued). Conversely, since REITs may also contract, we include the number of shares repurchased as a percentage of total shares outstanding at the end of the previous quarter (Number of Shares Repurchased). Our regressions also control for MREIT size, defined as the natural logarithm of total assets, which is lagged one quarter.

Our empirical model further includes the Federal Reserve's quarterly purchases of U.S. Treasuries and Agency MBS - each as a share of newly issued securities. While MREITs do not invest in Treasury securities, central bank purchases of Agency MBS can be viewed as directly reflecting the portfolio balance channel associated with QE for MREITs. Equation (1) summarizes these relationships, which are estimated via OLS with standard errors clustered by firm. L. denotes the lag operator.

14 This approach precludes being able to include MREIT fixed effects. 


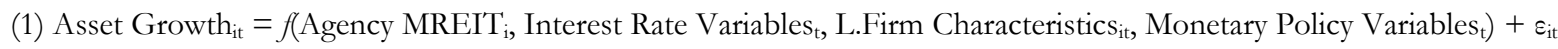

To examine different responses to Agency MBS purchases by the central bank across MREIT types, we augment Equation (1) by interacting the purchase share variable (overall or during specific periods) with the Agency MREIT indicator.

We next examine equity issuance, given its important role in supporting MREIT growth. Equation (2) shows the regression for equity issuance (an indicator for Issued Equity) in the same general framework, using interest rate variables, firm characteristics, and monetary policy variables as predictors, and separately augmenting the model by interacting the Agency MREIT indicator with the Federal Reserve Agency MBS purchase share variable.

(2) Equity Issuance $_{i t}=f\left(\right.$ Agency MREIT $_{\mathrm{i}}$, Interest Rate Variables $_{\mathrm{t}}$, L.Firm Characteristics $_{\mathrm{it}}$, Monetary Policy Variables $\left.\mathrm{t}\right)+\varepsilon_{\mathrm{it}}$

Here the relevant firm characteristics are size (as defined previously) and the lagged value of the MREITs' market-to-book ratio of equity, which captures market timing considerations that drive equity issuance decisions (Baker and Wurgler, 2000). All regressions are estimated via OLS with standard errors clustered by firm.

\subsection{Results}

Table 4 presents the results of our asset growth regressions. Not surprisingly, MREIT growth is strongly positively associated with the amount of equity issued and negatively related to share repurchases. This reflects the strict pay-out requirements for REITs and the resulting reliance on external funding to finance any material growth. We also find that Agency MREITs grew more during our sample period than Non-Agency MREITs

-- especially during QE2 when the Federal Reserve halted its Agency MBS purchases. However, Agency MREIT growth was negatively related to the Federal Reserve's Agency MBS purchases relative to new issuance during QE3 and the Tapering period. This is consistent with Agency MREITs facing reduced investment opportunities as the central bank re-entered the Agency MBS market.

[Table 4 about here.] 
Given the important role of equity issuance for Agency MREIT growth, we examine this directly in Table 5. In each case, lagged market-to-book ratios are positive and statistically significant - consistent with market timing considerations. We also see that Agency MREITs, on average, were more likely to issue equity than other MREITs over the entire sample. However, the Federal Reserve's QE program had very different implications for each type of MREIT. Agency MREITs issued significantly more equity than Non-Agency MREITs during QE2. However, during QE3 and the Tapering, equity issuance significantly increased for NonAgency MREITs and decreased for Agency MREITs. These results are again consistent with the central bank crowding-out private investment in Agency MBS as per the portfolio balance channel of monetary policy.

[Table 5 about here.]

\section{QE and Agency MREIT Risk Taking}

To identify the effects of unconventional monetary policy on Agency MREIT risk-taking, we again rely on the cross-sectional comparison to all other MREITs as a control group, consistent with the approach in Chakraborty, Goldstein and MacKinlay (2017).

\subsection{Empirical Approach}

We explore various MREIT risk measures in a similar framework as asset growth and equity issuance: (i) the ratio of equity to total assets (solvency risk); (ii) the ratio of repurchase agreements to total assets, and very short-term repo (<30 days) as a share of total repo debt (liquidity risk); and (iii) the ratio of cash and cash equivalents to total assets (liquidity risk). Equation (3) summarizes these relationships, where each of the risk measures are again related to the interest rate variables, lagged firm characteristics, and monetary policy variables. The model is estimated via OLS with standard errors clustered by firm.

(3) Risk $=f\left(\right.$ Agency MREIT ${ }_{i t}$, Interest Rate Variables ${ }_{t}$, L.Firm Characteristics M $_{i t}$ Monetary Policy Variables $\left._{t}\right)+\varepsilon_{i t}$

The firm characteristics in Equation (3) are lagged values of firm size and other risk characteristics, depending on the specification. 
Finally, for a sub-set of MREITs, we examine variation in two measures of interest rate risk exposure: (i) the ratio of fixed-rate Agency MBS to total Agency MBS; and (ii) the ratio of interest rate swaps and swaptions to total liabilities. Equation (4) summarizes these relationships, where the dependent variables are related to the same set of interest rate and monetary policy variables, as well as three lagged firm characteristics: the ratios of equity to total assets, short-term repo to total repo, and cash to total assets. As before, we estimate the model via OLS with standard errors clustered by firm.

(4) Interest Rate Risk $=f\left(\right.$ Agency MREIT $\mathrm{T}_{\mathrm{it}}$, Interest Rate Variables $\mathrm{t}$, L.Firm Charateristics $\mathrm{it}_{\mathrm{t}-1}$, Monetary Policy Variables $\left.\mathrm{t}\right)+\varepsilon_{\mathrm{it}}$

In all of these regressions, interactions between the Federal Reserve Agency MBS purchase shares and the Agency MREIT indicator are added separately, as before.

\subsection{Results}

In Table 6, we find that MREIT equity-to-assets ratios are consistently positively related to cash holdings and negatively related to the option-adjusted spread and firm size. We also see that Agency MREITs have significantly lower equity-to-assets ratios overall. MREITs collectively experienced a decline in their equity-toassets (i.e., increased leverage) in relation to the Federal Reserve's Agency MBS purchase activity during QE1. Agency MREITs experienced further declines during QE3 in proportion to Federal Reserve Agency MBS purchase activity; a time in which Non-Agency MREITs were increasing capital buffers. This suggests reaching for yield by Agency MREITs in the face of unconventional monetary policy through increased leverage.

[Table 6 about here.]

Table 7 explores variation in MREIT use of repurchase agreements for financing and see that this is negatively related to their cash holdings. Not surprisingly, we also find that Agency MREITs finance themselves much more intensively using repurchase agreements. However, we find little relationship between QE and MREIT repo financing activity, with the exception of the Federal Reserve's Agency MBS purchase share during the Tapering period.

[Table 7 about here.] 
Table 8 studies the composition of repo financing by exploring variation in the ratio of very short-term repo (<30 days) to total repo. Here, we again see a positive relationship with the Agency MREIT indicator consistent with their business model. Agency MREITs then shortened the maturity of their repurchase agreements in response to the Federal Reserve's Agency MBS purchases during QE1. Finally, during QE3, while Non-Agency MREITs increased their use of very short-term repurchase agreements in response to the Federal Reserve's purchase activity, Agency MREITs decreased their usage.

[Table 8 about here.]

Finally, in Table 9, we see that MREIT's ratios of cash to total assets are positively related to their equityto-assets ratios - consistent with the relationship found in Table 6. In terms of QE, Non-Agency MREITs hold significantly less cash in response to the Federal Reserve's Agency MBS purchases during the Tapering period, although Agency MREITs did not (i.e., the net effect is statistically zero).

[Table 9 about here.]

Turning to interest rate risk exposure, Table 10 presents the results of regressions considering variation in MREIT shares of fixed-rate Agency MBS holdings. Here we find that Agency MREITs consistently hold more fixed-rate securities than their Non-Agency counterparts. Moreover, the share of fixed-rate securities to total assets increases for all MREITs during QE3 and, to some extent, the Tapering period.

\section{[Table 10 about here.]}

Finally, Table 11 studies the intensity of interest rate hedging by MREITs as proxied by the ratio of interest rate swaps and swaptions to total liabilities. (Agency MBS investment often involves significant maturity transformation through repo debt financing, which is then hedged using interest rate derivatives.) Here we find that Agency MREITs typically hedge their liabilities more intensively. In Column (2) we see that hedging by Non-Agency MREITs decreased in proportion to the Federal Reserve's Agency MBS purchase share, but that the reverse was true of Agency MREITs. This result is primarily driven by central bank activity during the Tapering period. 
[Table 11 about here.]

Taken together, our results suggest that the Federal Reserve's Agency MBS purchase activity had important effects on Agency MREIT growth and risk-taking. In terms of growth, we document that Agency MREITs grew markedly during QE2 and subsequently receded during QE3 in relation to the Federal Reserve's Agency MBS purchase activity. This is consistent with the Federal Reserve's activity in the Agency MBS market crowding-out private-sector investment. In terms of risk-taking, we present evidence that Agency MREITs significantly increased their total leverage in response to the Federal Reserve's Agency MBS purchase activity during QE3, consistent with greater risk-taking by these institutions at a time when their organic growth prospects were reduced. However, during QE3 and the Tapering, these institutions seemed to engage in assetliability management consistent with the policy environment by holding more floating rate securities, lengthening liabilities, and increasing hedging.

\section{Conclusions}

The prolonged use of unconventional monetary policy since the financial crisis resulted in concerns about the potential for such policy accommodation to undermine financial stability. Indeed, some recent research finds evidence consistent with "reaching for yield" behavior by financial institutions during this time via increased credit risk-taking. This paper contributes to that literature by studying Agency MREITs, a group of specialized, tax-exempt financial institutions whose rapid growth raised systemic risk concerns by the Financial Stability Oversight Council. We believe that this analysis is important for at least two reasons. First, this is the first empirical analysis of Agency MREITs; these shadow banks could play a central role in the $\$ 5.8$ trillion Agency MBS market given the government-induced shrinkage of such holdings by Fannie Mae and Freddie Mac and the Federal Reserve's balance sheet normalization. Second, given that Agency MREITs do not takeon much credit risk, we are able to focus on whether these institutions altered instead their leverage, liquidity risk, and interest rate risk profiles during QE.

We conducted three sets of analyses to better understand the behavior of Agency MREITs after the recent financial crisis and in the context of the Federal Reserve's QE. The first was a high-frequency event study of 
the equity market reactions across Agency and Non-Agency MREITs to various central bank announcements. Here we found that Agency MREITs reacted to most announcements, did so in a manner consistent with their business prospects, and reacted differently from Non-Agency MREITs, other financial institutions, as well as the broader market. Second, we studied Agency MREIT asset growth and equity issuance and find that this was generally inversely associated with the Federal Reserve's Agency MBS purchase activity during QE2 and QE3. We regard this as novel evidence for the central bank directly crowding-out private investment as per the portfolio balance channel. Our third analysis focuses on the relationship between Agency MREIT risktaking and QE. Here we find that, during QE3, Agency MREITs increased their leverage in relation to the Federal Reserve's purchase activity -- consistent with "reaching for yield" by these institutions. However, the interest rate risk profiles of these institutions became more conservative during the Tapering period, by holding more floating rate securities, lengthening liabilities, and increasing hedging. 


\section{Bibliography}

Acharya, Viral and Hassan Naqvi, 2015. "On Reaching for Yield and the Coexistence of Bubbles and Negative Bubbles.” Available at: http://pages.stern.nyu.edu/ sternfin/vacharya/public_html/pdfs/yield31b.pdf

Adrian, Tobias and Hyun Shin, 2010. "Financial Intermediaries and the Price of Risk." Federal Reserve Bank of New York Staff Reports \#398 (May).

Aramonte, Sirio, Seung Lee, and Viktors Stebunovs, 2015. "Risk Taking and Low Longer-Term Interest Rates: Evidence from the U.S. Syndicated Loan Market.” Federal Reserve Board R\&S Working Paper 2015-068.

Baker, Malcolm and Jeffrey Wurgler. 2000. "The Equity Share in New Issues and Aggregate Stock Returns." Journal of Finance, 55(5): 2219-57.

Bauer, Michael and Glenn Rudebusch, 2014. "The Signaling Channel for Federal Reserve Bond Purchases." International Journal of Central Banking, x: 233-289.

Bernanke, Ben, 2010. "The Economic Outlook and Monetary Policy." Remarks at the Federal Reserve Bank of Kansas City Economic Symposium (August 27).

Bernanke, Ben, 2013. "Testimony before the Joint Economic Committee, U.S. Congress.” (May 22).

Borio, Claudio and Haibin Zhu, 2012. "Capital Regulation, Risk-Taking and Monetary Policy: A Missing Link in the Transmission Mechanism?” Journal of Financial Stability, 8: 236-251.

Chakraborty, Indraneel, Itay Goldstein, Itay and Andrew MacKinlay, 2017. "Monetary Stimulus and Bank Lending." Finance Down Under Conference Paper (December 20)

Choi, Jaewon and Mathias Kronlund, 2018. "Reaching for Yield by Corporate Bond Mutual Funds." Review of Financial Studies, 31(5): 1930-1965.

Chodorow-Reich, Gabriel, 2014. "The Effects of Unconventional Monetary Policy on Financial Institutions." Brookings Papers on Economic Activity (Spring): 155-204.

D'Amico, Stefania and Thomas King, 2013. "Flow and Stock Effects of Large-Scale Treasury Purchases: Evidence on the Importance of Local Supply." Journal of Financial Economics, 108(2): 425-48.

Delis, Manthos, Iftekhar Hasan, and Nikolas Mylolonidis, 2017. “The Risk-Taking Channel of Monetary Policy in the U.S.: Evidence from Corporate Loan Data," Journal of Money, Credit, and Banking, 49(1): 187-213.

Dell'Ariccia, Giovanni, Luc Leaven, and Gustavo Suarez, 2016. "Bank Leverage and Monetary Policy's RiskTaking Channel: Evidence from the United States," Journal of Finance, 72(2): 613-654.

DiMaggio, Marco and Marcin Kacperczyk, 2016. "The Unintended Consequences of the Zero Lower Bound Policy,” Journal of Financial Economics, 123(1): 59-80.

Feroli, Michael, Anil Kashyap, Kermit Schoenholtz, and Hyun Shin, 2014. "Market Tantrums and Monetary Policy," Chicago Booth Working paper 14-09.

https://papers.ssrn.com/sol3/papers.cfm?abstract_id=2409092

Frame, W. Scott, Andreas Fuster, Joseph Tracy, and James Vickery, 2015. “The Rescue of Fannie Mae and Freddie Mac." Journal of Economic Perspectives, 29(2): 25-52.

Gagnon, Joseph, Matthew Raskin, Julie Remache, and Brian Sack, 2010. "Large Scale Asset Purchases by the Federal Reserve: Did They Work?" Federal Reserve Bank of New York Staff Report 441 (March).

Gorton, Gary and Andrew Metrick, 2012. "Securitized Banking and the Run on Repo." Journal of Financial Economics, 104(3): 425-451.

Hamilton, James and Jing Cynthia Wu, 2012. "The Effectiveness of Alternative Monetary Policy Tools in a Zero Lower Bound Environment.” Journal of Money, Credit, and Banking, 44(1): 3-46. 
Hancock, Diana and Wayne Passmore, 2011. "Did the Federal Reserve's MBS Purchase Program Lower Mortgage Rates?” Journal of Monetary Economics, 58: 498-514.

Ioannidou, Vasso, Steven Ongena, and Jose Luis Peydro, 2015. "Monetary Policy, Risk-Taking, and Pricing: Evidence from a Quasi-Natural Experiment," Review of Finance, 19(1): 95-144.

Jimenez, Gabriel, Steven Ongena, Jose Luis Peydro, and Jesus Saurina, 2014. "Hazardous Times for Monetary Policy: What do 23 Million Loans Say about the Impact of Monetary Policy on Credit Risk-Taking?" Econometrica, 82: 463-505.

Kashyap, Anil and Jeremy Stein, 1995. "The Impact of Monetary Policy on Bank Balance Sheets." CarnegieRochester Conference Series on Public Policy, 42: 151-195

Krishnamurthy, Arvind and Annette Vissing-Jorgensen, 2011. "The Effects of Quantitative Easing on Interest Rates: Channels and Implications for Policy." Brookings Papers on Economic Activity, 215-265.

Morris, Stephen and Hyun Shin, 2016. "Risk Premium Shifts and Monetary Policy: A Coordination Approach" in Monetary Policy through Asset Markets: Lessons from Unconventional Measures and Implications for an Integrated World, edited by Michael Woodford, Diego Saravia and Elias Albagli. Banco Central de Chile.

Neely, Christopher, 2012. "Unconventional Monetary Policy Had Large International Effects." Journal of Banking and Finance, 52: 101-111.

Paligorova, Teodora and Joao Santos, 2017. "Monetary Policy and Bank Risk-Taking: Evidence from the Corporate Loan Market" Journal of Financial Intermediation, 30: 35-49.

Pellerin, Sabrina, Steven Sabol, and John Walter, 2013. “MBS Real Estate Investment Trusts: A Primer.” Federal Reserve Bank of Richmond Economic Quarterly, 99(3): 193-227.

Rajan, Raghuram, 2005. "Has Financial Development Made the World Riskier?" NBER Working Paper \#11728.

U.S. Financial Stability Oversight Council, 2013. Annual Report. 


\section{Figures and Tables}

Figure 1: Mortgage REIT Investment Shares (2005-2015, quarterly)

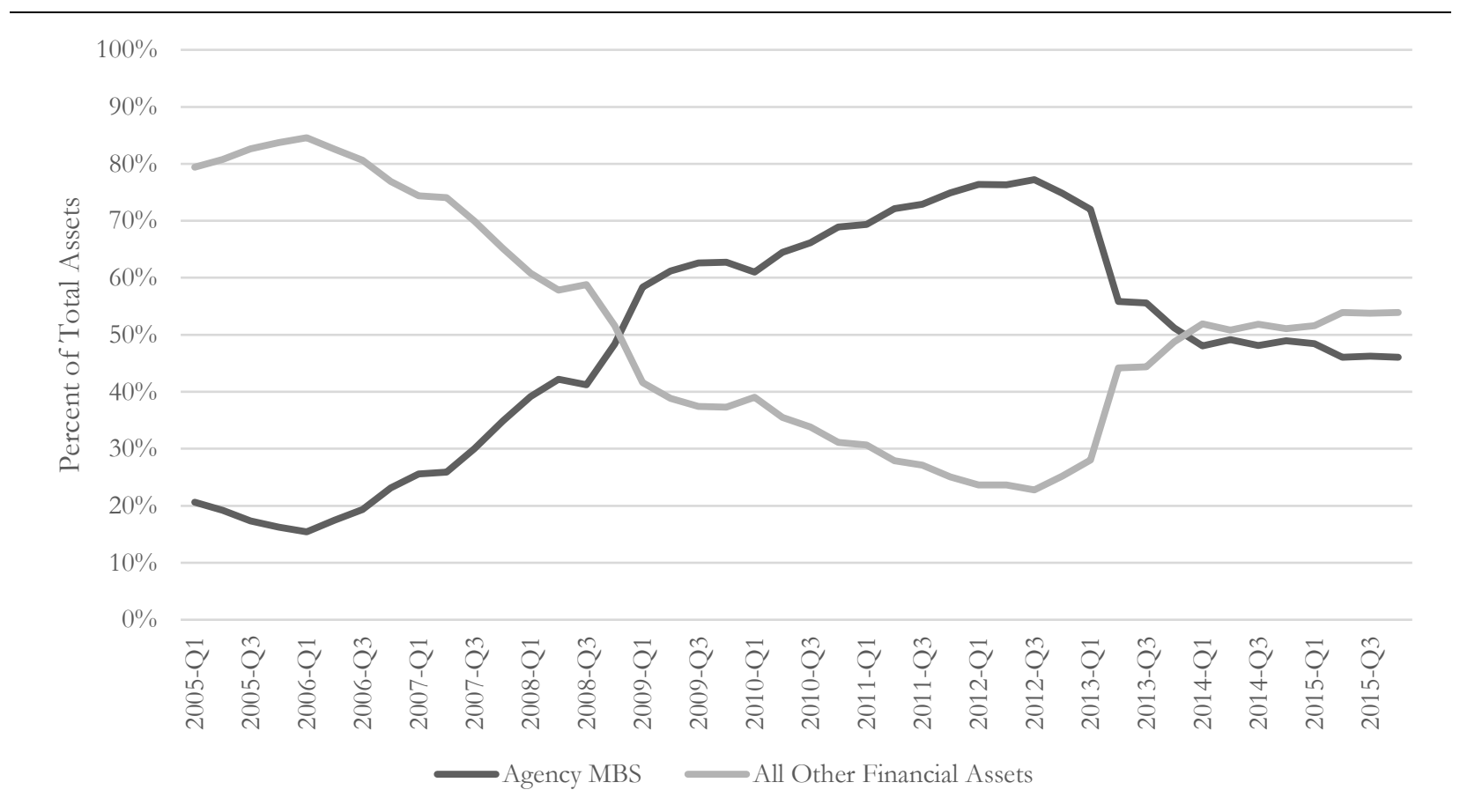

Source: Federal Reserve Flow of Funds 
Figure 2: Mortgage REIT Asset Profile and Number of Firms (2005-2015, quarterly)

\section{Panel A: Holdings of Agency MBS}

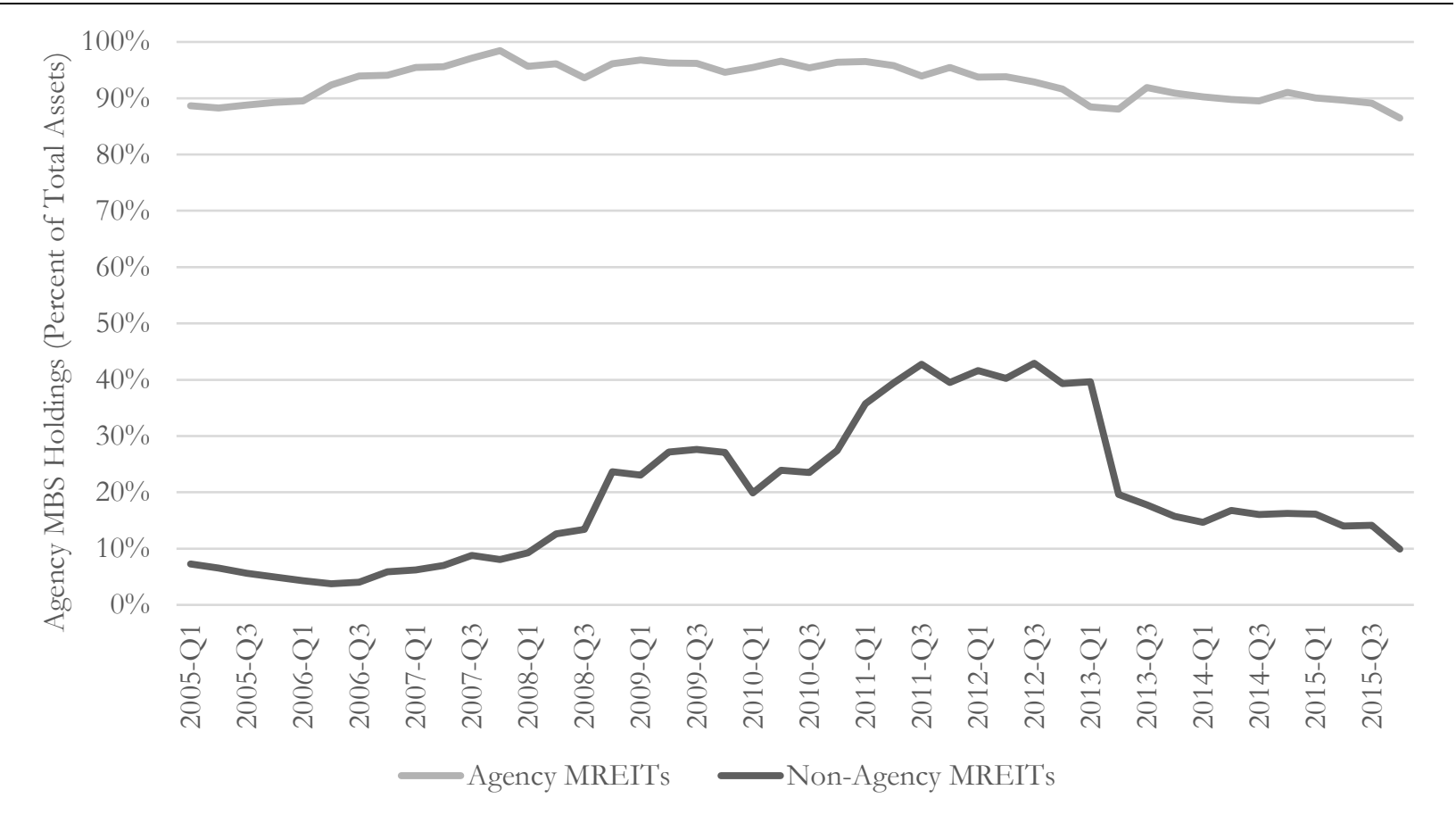

Panel B: Number of Mortgage REITs

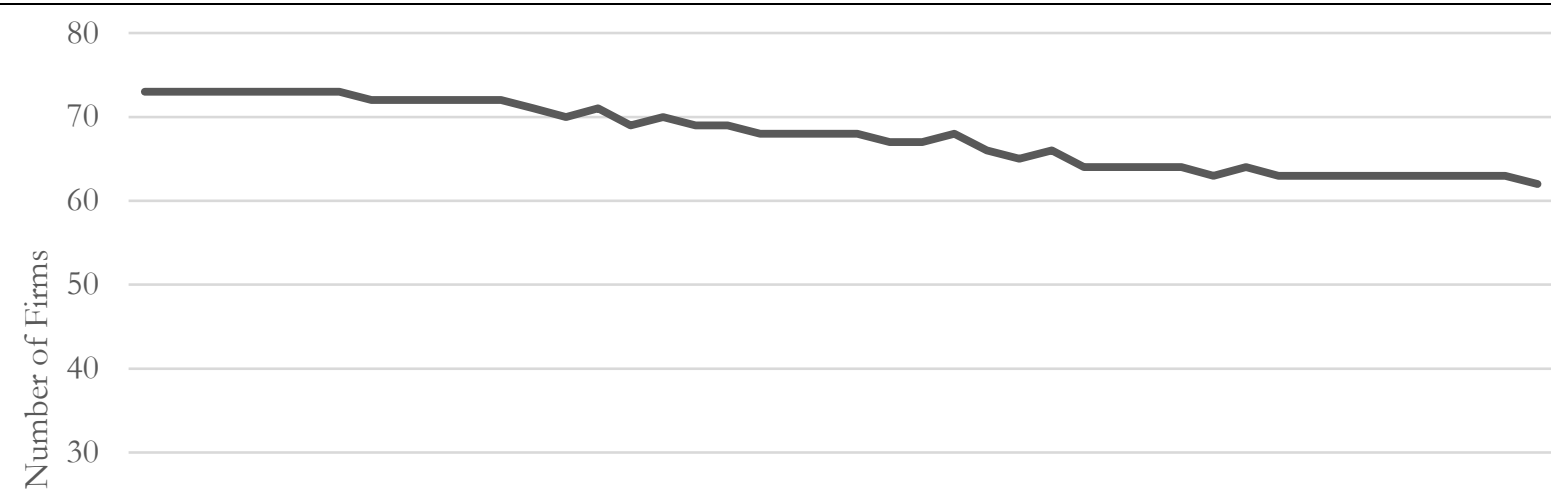

20

10

0

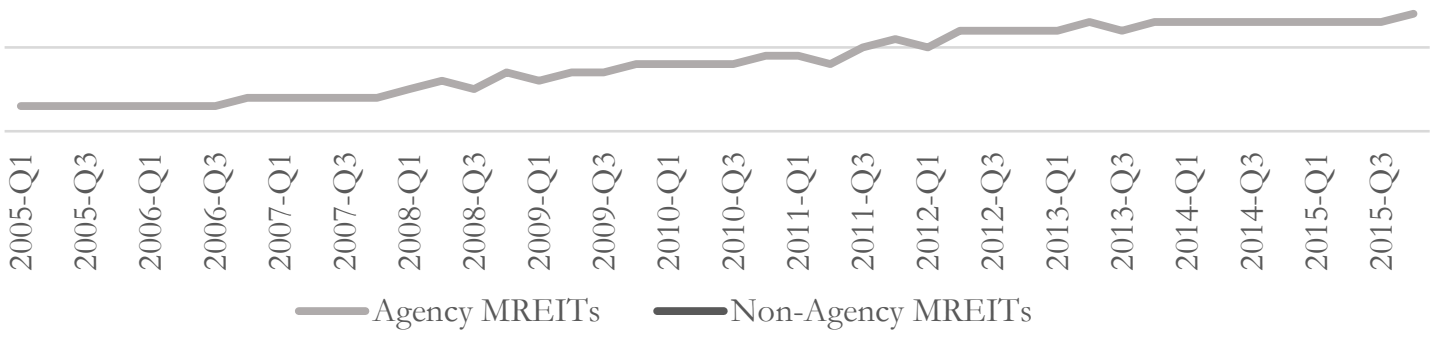

Source: S\&P Global 
Figure 3: MREIT Capital Structure (2005-2015, quarterly)

Panel A: Agency MREITs

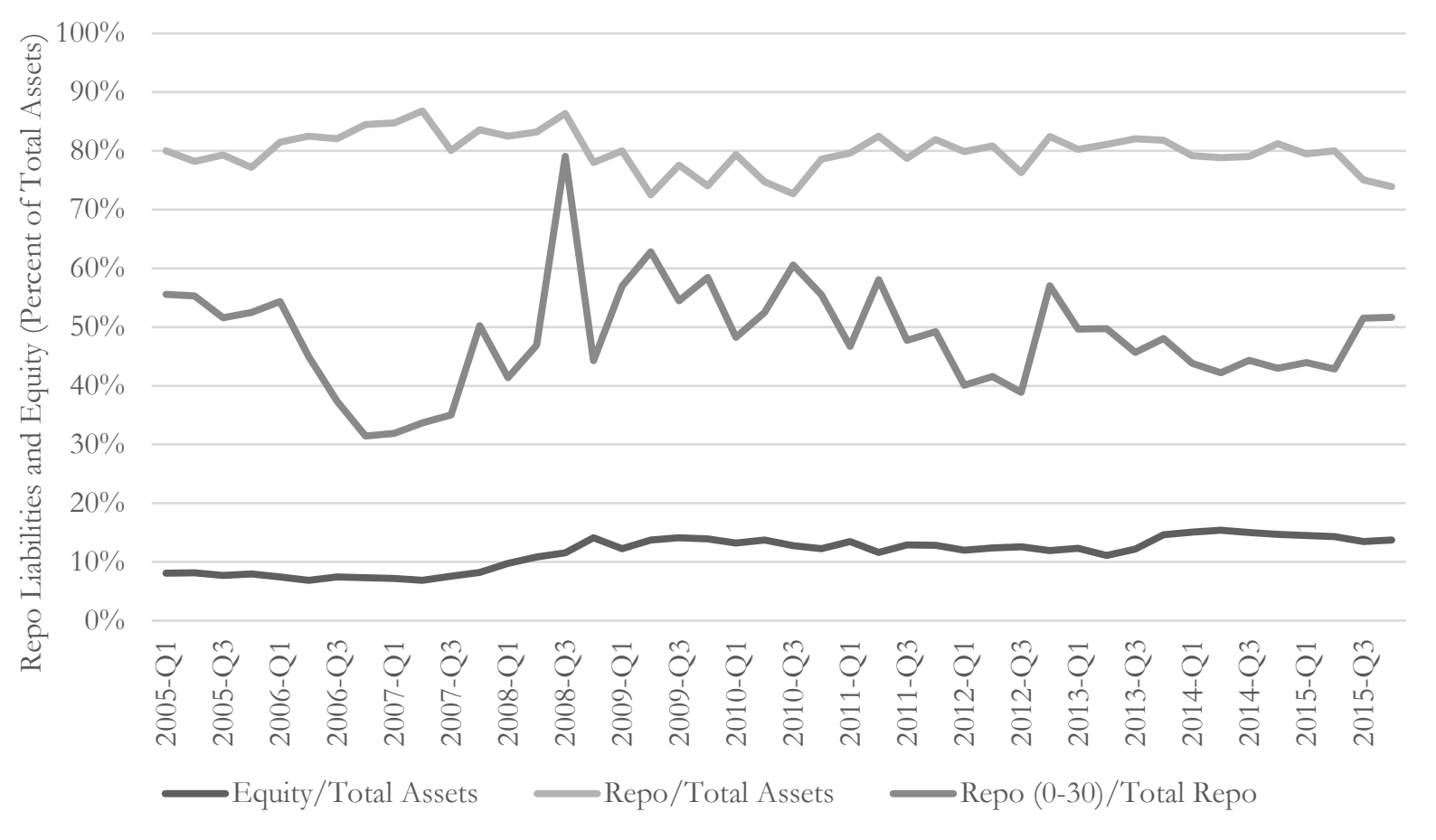

Panel B: Non-Agency MREITs

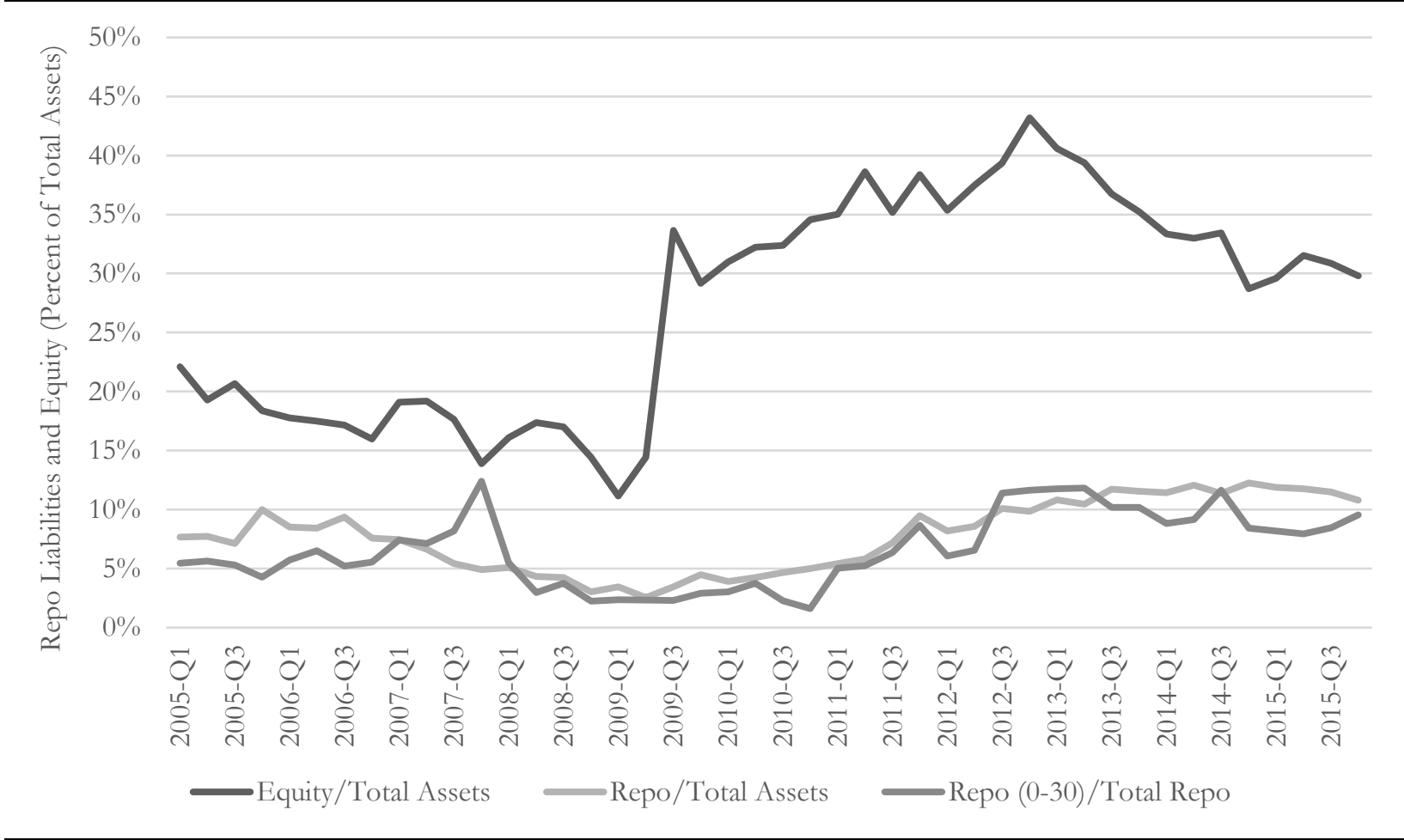

Source: S\&P Global 
Figure 4: Mortgage REIT Agency MBS Holdings and Market Share (2005-2015, quarterly)

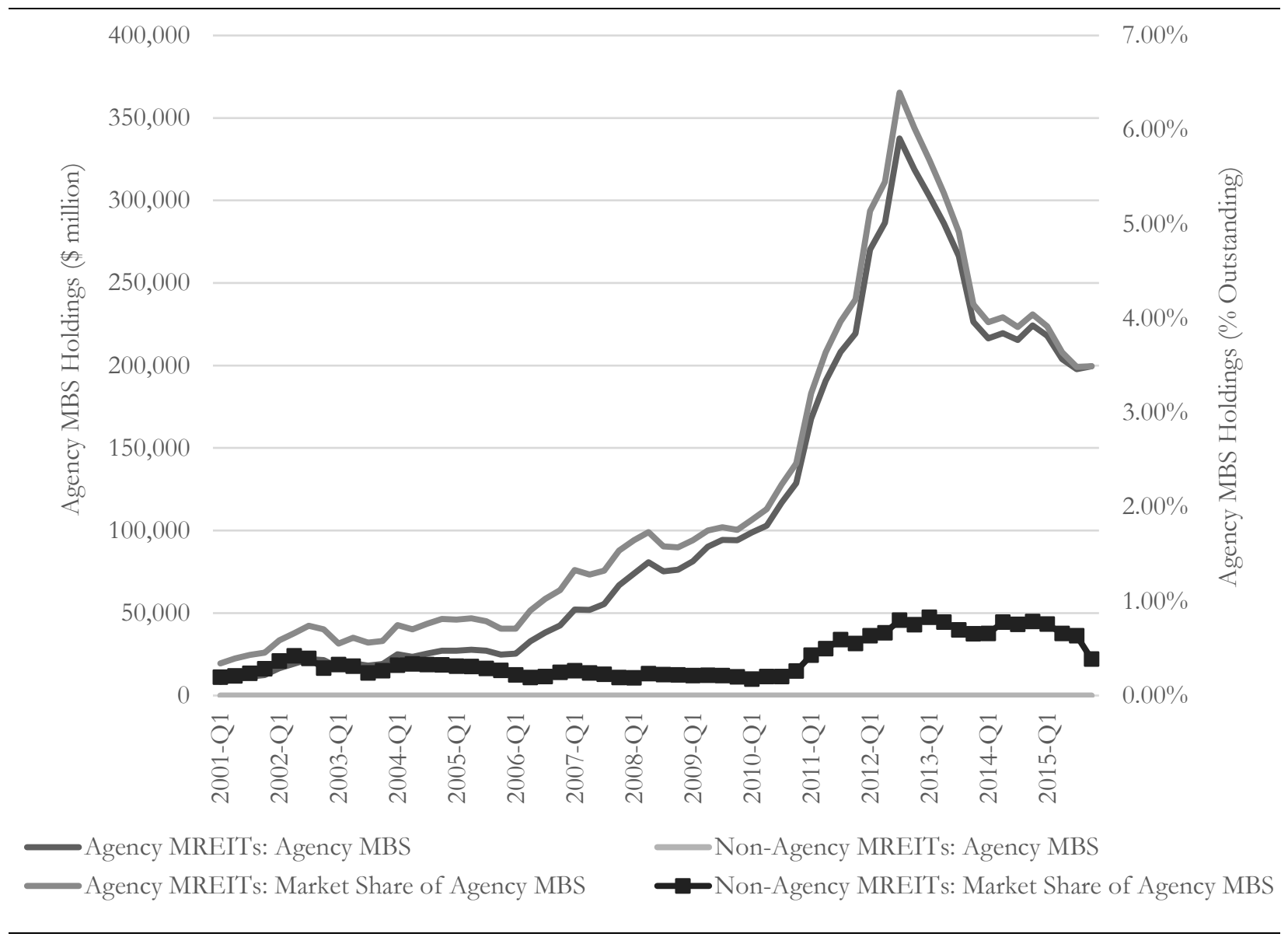

Source: S\&P Global, Federal Reserve Bank of New York 
Figure 5: Federal Reserve and GSE Agency MBS Market Shares (2008-2015, quarterly)

Panel A: Purchase Share (\% of Total Agency MBS Issuance)

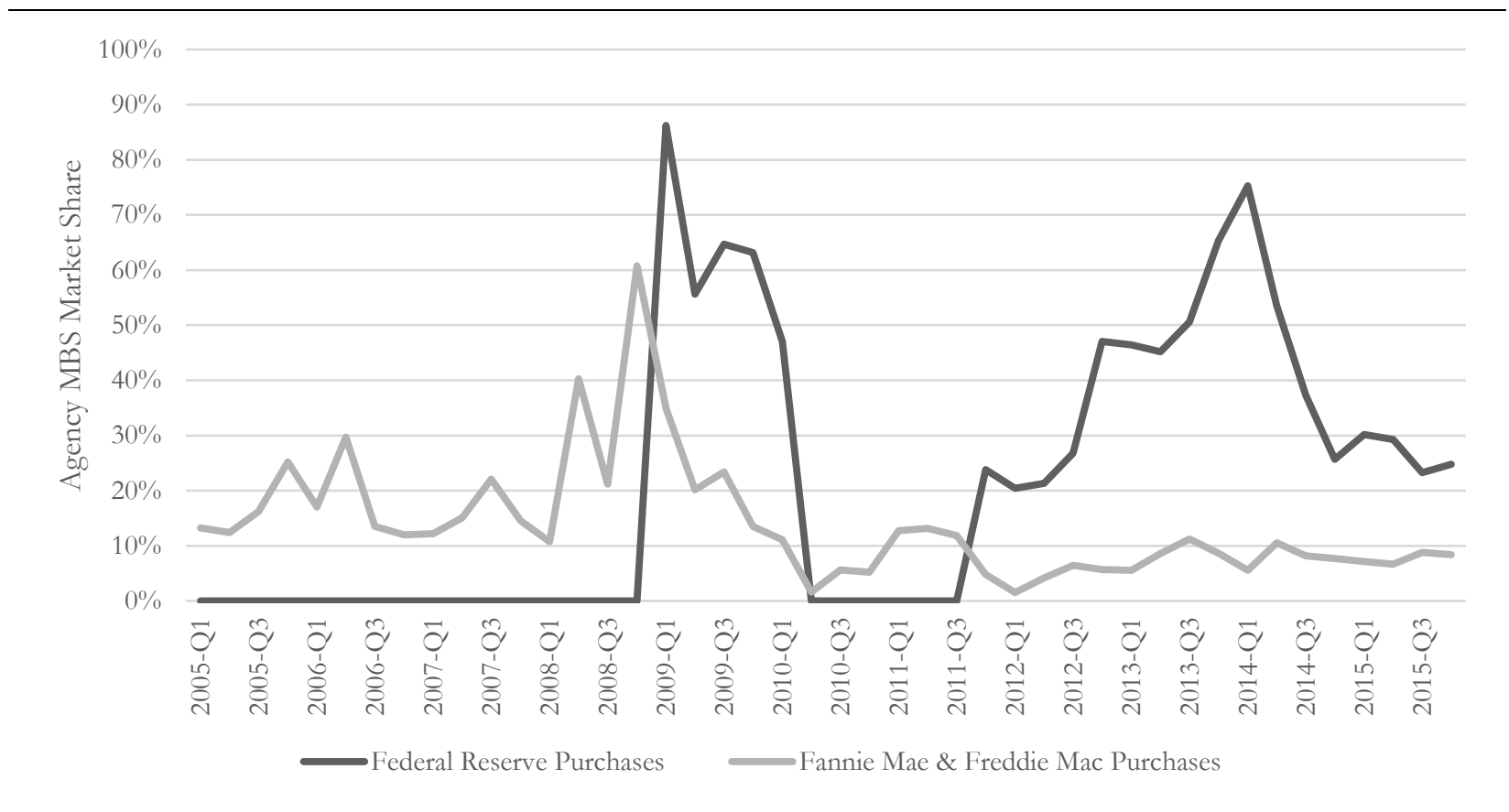

Panel B: Holdings Share (\% of Total Agency MBS Outstanding)

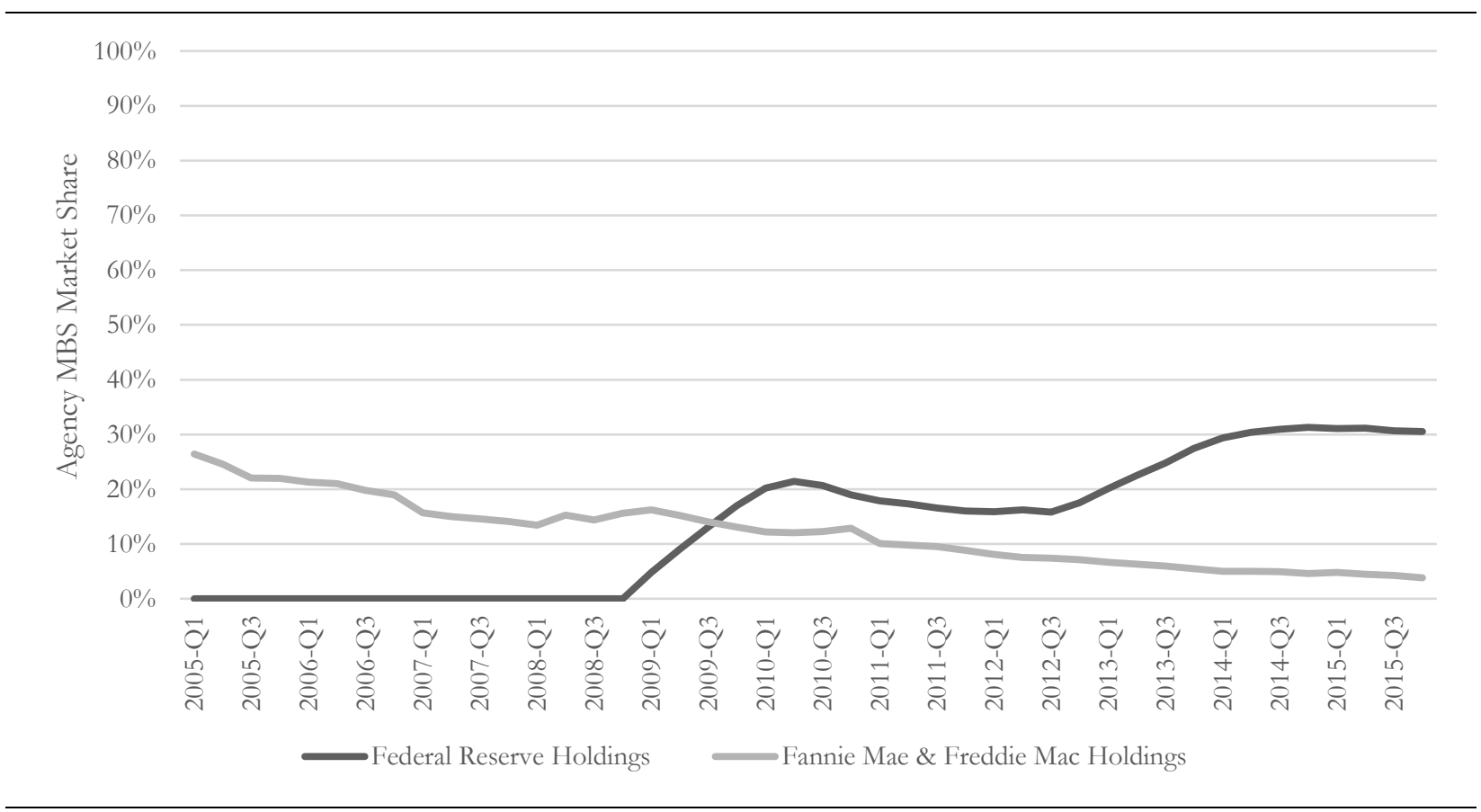

Source: Federal Reserve Bank of New York 
Figure 6: MREIT Equity Issuance (2005-2015, quarterly)

Panel A: Agency MREITs

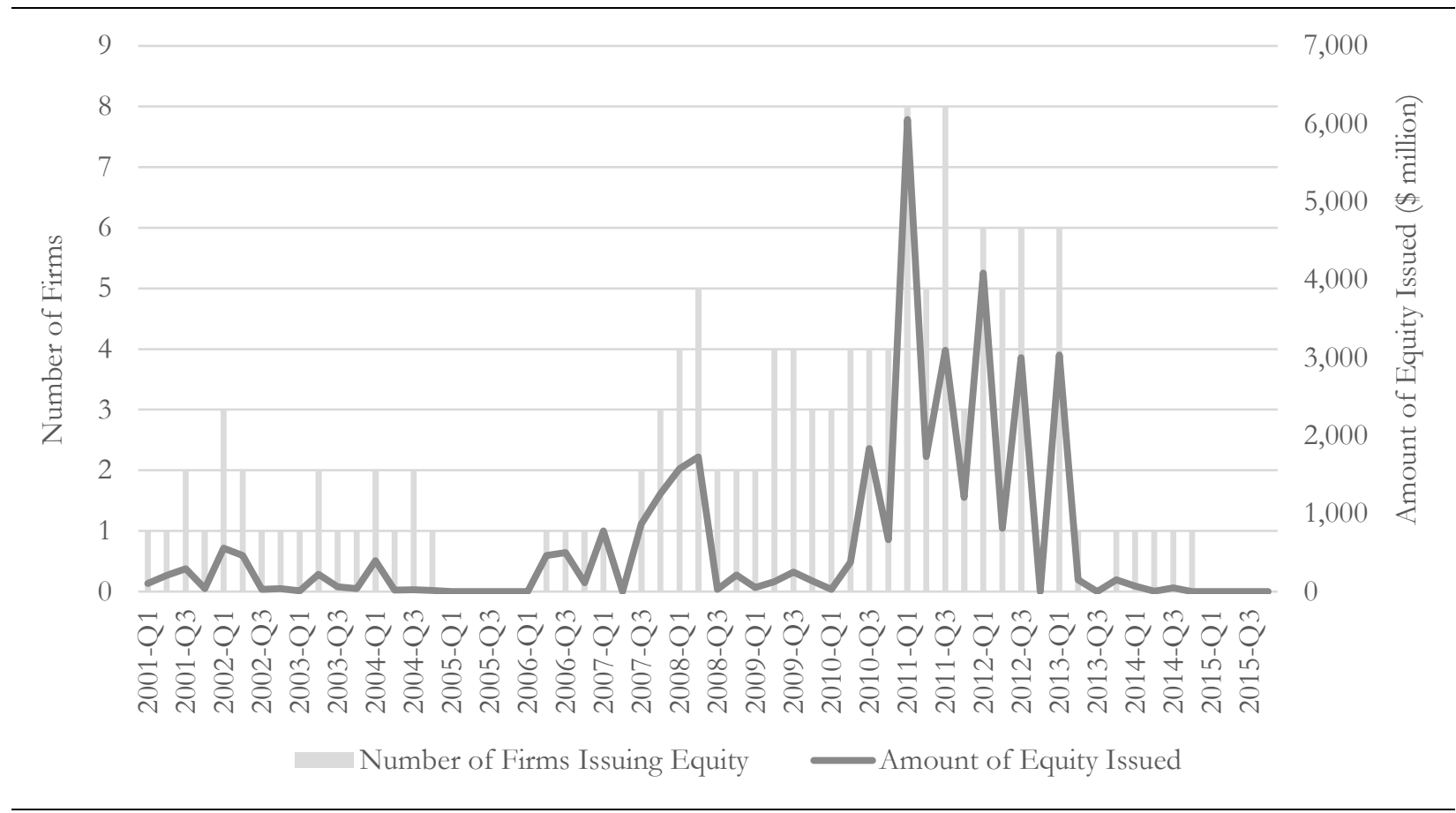

Panel B: Non-Agency MREITs

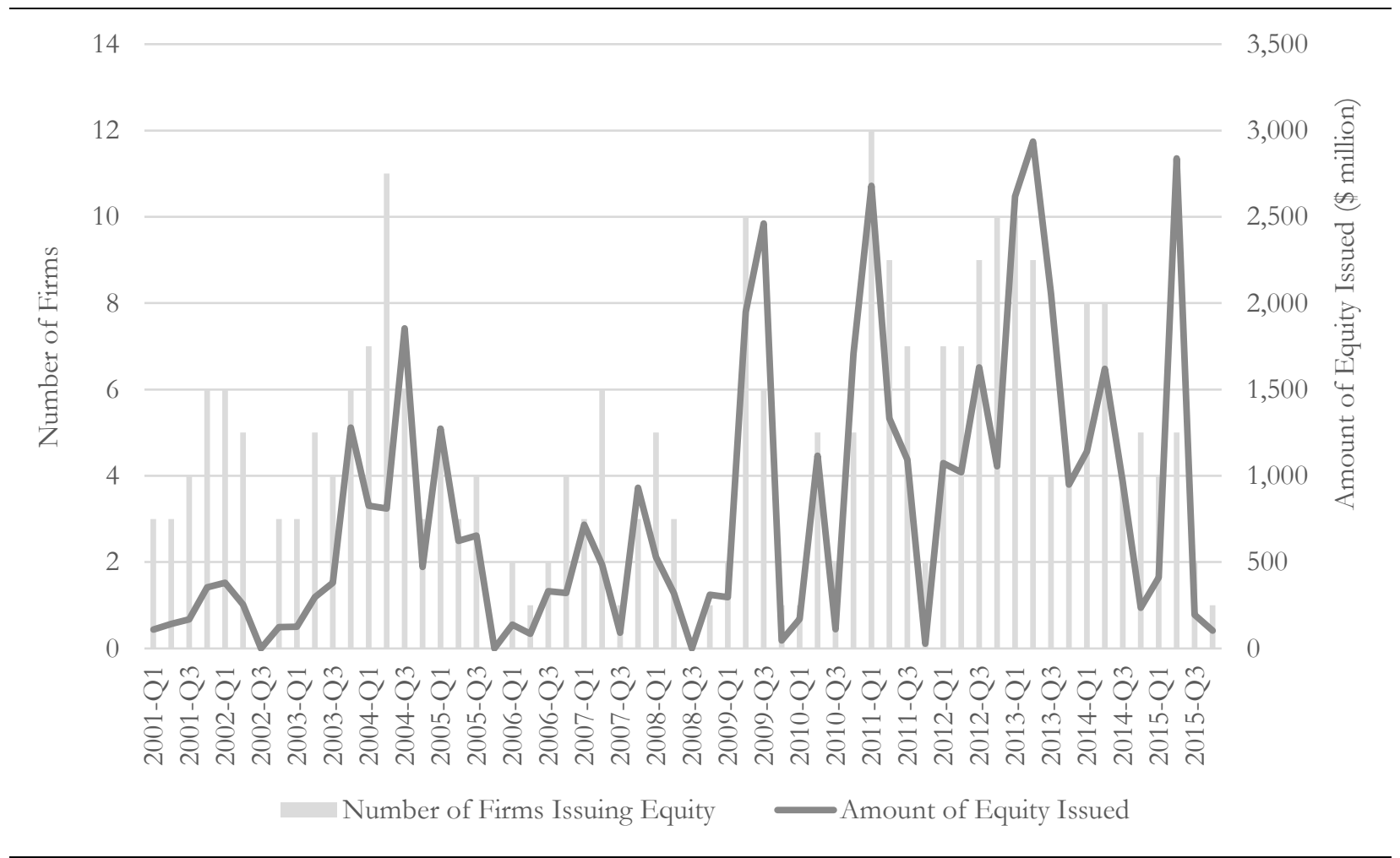

Source: S\&P Global 


\section{Table 1: Event Study}

This table presents the results from the event study. Difference is the difference in the estimates for Agency MREITs versus Non-Agency MREITs. Significance is indicated as follows: ${ }^{* * *} \mathrm{p}<0.01,{ }^{* *} \mathrm{p}<0.05,{ }^{*} \mathrm{p}<0.1$, respectively, based on the larger of the conventional or robust standard error from a regression of the change in the asset price on a constant on the date indicated. Periods are defined as follows: Initial QE: 12/16/2008 and 03/18/2009; Taper: 05/22/2013 and 06/19/2013; Sample end: 07/10/2013 and 09/18/2013. Totals may differ due to rounding or sample composition.

\begin{tabular}{|c|c|c|c|c|c|c|c|c|}
\hline Regime & Date & Treasury & Life Insurers & Banks & Market & $\begin{array}{l}\text { Agency } \\
\text { MREITs }\end{array}$ & $\begin{array}{c}\text { Non-Agency } \\
\text { MREITs }\end{array}$ & Difference \\
\hline QE1 & $12 / 01 / 2008$ & -9.2 & -0.4 & $-0.6^{* * *}$ & $-0.5^{* * *}$ & 0.3 & -0.6 & $0.9^{*}$ \\
\hline QE1 & $12 / 16 / 2008$ & -16.8 & $3.6 * * *$ & $2.2^{* * *}$ & $1.3^{* * *}$ & $1.2^{* * *}$ & $2.2^{* * *}$ & $-1.0 * *$ \\
\hline QE1 & $01 / 28 / 2009$ & 3.1 & $-1.2 * * *$ & -0.3 & $-0.3 * * *$ & 0.0 & $-0.7 * * *$ & $0.7 * * *$ \\
\hline QE1 & $03 / 18 / 2009$ & -22.8 & $4.0 * * *$ & $2.5^{* * *}$ & $1.5^{* * *}$ & $1.0 * *$ & $1.7 * *$ & -0.7 \\
\hline QE1 & $09 / 23 / 2009$ & -8.9 & $0.6^{* * *}$ & $0.6 * * *$ & $0.6^{* * *}$ & $0.4 * * *$ & $0.6 * * *$ & $-0.2^{*}$ \\
\hline QE2 & $08 / 10 / 2010$ & -5.8 & $0.8^{* * * *}$ & $0.9 * * *$ & $0.7 * * *$ & $0.4 * * *$ & $0.5^{* * *}$ & -0.1 \\
\hline QE2 & $09 / 21 / 2010$ & -1.8 & $0.6 * * *$ & $0.7 * * *$ & $0.5^{* * *}$ & $0.1 * *$ & 0.1 & 0.0 \\
\hline $\mathrm{FG}$ & $08 / 09 / 2011$ & -14.4 & $-2.0 * * *$ & $-1.7 * * *$ & $-1.4^{* * *}$ & $1.7 * *$ & -0.4 & $2.1 * * *$ \\
\hline FG & $01 / 25 / 2012$ & -6.3 & $-0.6 * * *$ & 0.0 & $0.3^{* * *}$ & $0.6 * * *$ & $0.3^{* * *}$ & $0.3^{*}$ \\
\hline QE3 & $09 / 13 / 2012$ & 6.4 & $1.3^{* * *}$ & $1.0 * * *$ & $0.5^{* * *}$ & $0.3 * * *$ & $0.3^{* * *}$ & 0.0 \\
\hline QE3 & $05 / 22 / 2013$ & 6.6 & $-0.4^{* * *}$ & $-0.5^{* * *}$ & $-0.5^{* * *}$ & $-1.2^{* * *}$ & $-0.5^{* * *}$ & $-0.7 * *$ \\
\hline QE3 & $06 / 19 / 2013$ & 7.8 & 0.1 & $0.2^{* * *}$ & $-0.2^{* * *}$ & $-1.3^{* * *}$ & $-0.6 * * *$ & $-0.7 * *$ \\
\hline QE3 & $07 / 10 / 2013$ & -7.3 & 0.3 & 0.0 & $0.3 * * *$ & 0.5 & 0.5 & 0.0 \\
\hline QE3 & $09 / 18 / 2013$ & -14.0 & 0.4 & $0.9 * * *$ & $1.0 * * *$ & $2.8^{* * *}$ & $1.8^{* * *}$ & $1.0^{* * *}$ \\
\hline \multicolumn{2}{|c|}{ Initial QE } & -39.7 & $7.6^{* * *}$ & $4.5^{* * *}$ & $2.9 * * *$ & $2.2^{* * *}$ & $4.0^{* * *}$ & $-1.9 *$ \\
\hline \multicolumn{2}{|c|}{ Taper } & 14.4 & $-0.3 * * *$ & $-0.4 * * *$ & $-0.6 * * *$ & $-2.5^{* * *}$ & $-1.1 * * *$ & $-1.3 * *$ \\
\hline \multicolumn{2}{|c|}{ Sample end } & -21.4 & 0.4 & $0.9 * * *$ & 1.2 & $3.2^{* * *}$ & $1.9 * * *$ & $1.2^{* * *}$ \\
\hline
\end{tabular}


Table 2: Timeline of Federal Reserve Policy Actions: 2008-2014

\begin{tabular}{|c|c|c|c|c|c|}
\hline & Announcement Date & Target End Date & $\begin{array}{l}\text { Targeted Total } \\
\text { Purchases }\end{array}$ & $\begin{array}{l}\text { Composition of } \\
\text { Purchases }\end{array}$ & Program Details as Announced \\
\hline \multirow{4}{*}{$\begin{array}{l}\text { Quantitative Easing } 1 \\
\text { (QE1) } \\
\text { December } 2008 \text { - March } \\
2010\end{array}$} & November 25, 2008 & Over Several Quarters & $\begin{array}{l}\text { Agency Debt: Up to } \\
\$ 100 \text { b } \\
\text { Agency MBS: Up to } \\
\$ 500 \text { b }\end{array}$ & $\begin{array}{l}\text { Agency Debt and } \\
\text { Agency MBS }\end{array}$ & $\begin{array}{l}\text { Purchase up to } \$ 100 \mathrm{~b} \text { of agency debt } \\
\text { and up to } \$ 500 \mathrm{~b} \text { of Agency MBS. } \\
\text { Purchases expected to take place over } \\
\text { several quarters. }\end{array}$ \\
\hline & December 16, 2008 & --- & --- & --- & $\begin{array}{l}\text { Lowered the Fed Funds rate to } \\
\text { effective lower bound and stated that } \\
\text { this was likely to remain for "some } \\
\text { time". }\end{array}$ \\
\hline & March 18, 2009 & $\begin{array}{l}\text { Treasury Securities: } \\
\text { September 30, } 2009 \\
\text { (Completed Oct. } \\
\text { 2009) }\end{array}$ & $\begin{array}{l}\text { Agency Debt: Add } \\
\$ 100 \text { b } \\
\text { Agency MBS: Add } \\
\$ 750 \text { b } \\
\text { Long-Term }\end{array}$ & $\begin{array}{l}\text { Agency Debt, } \\
\text { Agency MBS, and } \\
\text { Long-Term } \\
\text { Treasuries }\end{array}$ & $\begin{array}{l}\text { Total purchases of Agency MBS will } \\
\text { now be up to } \$ 1.25 \mathrm{t} \text { and agency debt } \\
\text { up to } \$ 200 \mathrm{~b} \text {. Purchase up to } \$ 300 \mathrm{~b} \text { of } \\
\text { long-term Treasury securities over the } \\
\text { next six months. }\end{array}$ \\
\hline & & $\begin{array}{l}\text { Agency Debt \& MBS } \\
\text { December 31, } 2009 \\
\text { (Completed Mar. } \\
\text { 2010) }\end{array}$ & Treasuries: $\$ 300 \mathrm{~b}$ & & $\begin{array}{l}\text { Rates likely to remain at the effective } \\
\text { lower bound for an "extended period". }\end{array}$ \\
\hline $\begin{array}{l}\text { Quantitative Easing } 2 \\
\text { (QE2) }\end{array}$ & November 3, 2010 & June 30, 2011 & $\begin{array}{l}\text { Long-Term } \\
\text { Treasuries: } \$ 600 \mathrm{~b}\end{array}$ & $\begin{array}{l}\text { Long-Term } \\
\text { Treasuries }\end{array}$ & $\begin{array}{l}\text { Purchase } \$ 600 \mathrm{~b} \text { of long-term Treasury } \\
\text { securities by the end of } 2011: \mathrm{Q} 2 \text { at a } \\
\text { pace of about } \$ 75 \text { per month. }\end{array}$ \\
\hline $\begin{array}{l}\text { November } 2010 \text { - June } 2011 \\
\text { Policy Normalization } \\
\text { Principles }\end{array}$ & June 22, 2011 & --- & --- & --- & \\
\hline $\begin{array}{l}\text { Maturity Extension } \\
\text { Program (MEP) \& } \\
\text { Forward Guidance }\end{array}$ & August 9, 2011 & --- & --- & --- & $\begin{array}{l}\text { Rates likely to remain at the effective } \\
\text { lower bound at least until mid- } 2013 \text {. }\end{array}$ \\
\hline \multirow[t]{3}{*}{$\begin{array}{l}\text { MEP: September } 2011- \\
\text { December } 2012\end{array}$} & September 21, 2011 & June 30, 2012 & $\begin{array}{l}\text { Long-Term } \\
\text { Treasuries: } \$ 400 \mathrm{~b}\end{array}$ & $\begin{array}{l}\text { Long-Term } \\
\text { Treasuries }\end{array}$ & $\begin{array}{l}\text { Purchase, by the end of } 2012: \mathrm{Q} 2 \text {, } \\
\$ 400 \text { b of Treasuries with remaining } \\
\text { maturities between } 6-30 \text { years and sell } \\
\text { an equal amount of Treasury securities } \\
\text { with remaining maturities of } 3 \text { years or } \\
\text { less. }\end{array}$ \\
\hline & January 25, 2012 & --- & --- & --- & $\begin{array}{l}\text { Rates likely to remain at the effective } \\
\text { lower bound at least through late } 2014 \text {. }\end{array}$ \\
\hline & June 20, 2012 & December 31, 2012 & $\begin{array}{l}\text { Amount Limited by } \\
\text { Remaining Short- } \\
\text { Term Treasuries }\end{array}$ & $\begin{array}{l}\text { Long-Term } \\
\text { Treasuries }\end{array}$ & $\begin{array}{l}\text { Purchase Treasuries with remaining } \\
\text { maturities between } 6-30 \text { years at the } \\
\text { current pace and sell or redeem an } \\
\text { equal amount of Treasury securities }\end{array}$ \\
\hline
\end{tabular}


with remaining maturities of approximately 3 years or less.

\begin{tabular}{|c|c|c|c|c|}
\hline $\begin{array}{l}\text { Quantitative Easing } 3 \\
\text { (QE3) }\end{array}$ & September 13, 2012 & None Given & None Given & $\begin{array}{l}\text { Agency MBS and } \\
\text { Long-Term } \\
\text { Treasuries }\end{array}$ \\
\hline
\end{tabular}

September 2012 -

December 2013

$\begin{array}{ll}\text { December 12, } 2012 \quad \text { None Given } & \text { Agency MBS and } \\ & \\ & \text { Long-Term } \\ & \text { Treasuries }\end{array}$

Purchase Agency MBS at a pace of

$\$ 40 \mathrm{~b}$ per month and continue Twist

through year-end, increasing holdings of long-term securities in aggregate by $\$ 85 b$.

Rates likely to remain at the effective lower bound at least through mid-2015. Purchase Agency MBS at a pace of $\$ 40 \mathrm{~b}$ per month and long-term

Treasuries at a pace of $\$ 45 \mathrm{~b}$ per month after Twist ends at year-end.

Rates likely to remain at the effective lower bound, but now conditional on economic indicators.

\begin{tabular}{|c|c|c|c|c|c|}
\hline \multirow[t]{6}{*}{ Tapering } & December 18, 2013 & None Given & None Given & $\begin{array}{l}\text { Agency MBS and } \\
\text { Long-Term } \\
\text { Treasuries }\end{array}$ & $\begin{array}{l}\text { Purchase Agency MBS at a pace of } \\
\$ 35 \mathrm{~b} \text { per month and long-term } \\
\text { Treasuries at a pace of } \$ 40 \mathrm{~b} \text { per month } \\
\text { after Twist ends at year-end. }\end{array}$ \\
\hline & January 29, 2014 & None Given & None Given & $\begin{array}{l}\text { Agency MBS and } \\
\text { Long-Term } \\
\text { Treasuries }\end{array}$ & $\begin{array}{l}\text { Purchase Agency MBS at a pace of } \\
\$ 30 \mathrm{~b} \text { per month and long-term } \\
\text { Treasuries at a pace of } \$ 35 \mathrm{~b} \text { per month } \\
\text { after Twist ends at year-end. }\end{array}$ \\
\hline & March 19, 2014 & None Given & None Given & $\begin{array}{l}\text { Agency MBS and } \\
\text { Long-Term } \\
\text { Treasuries }\end{array}$ & $\begin{array}{l}\text { Purchase Agency MBS at a pace of } \\
\$ 25 \mathrm{~b} \text { per month and long-term } \\
\text { Treasuries at a pace of } \$ 30 \mathrm{~b} \text { per month } \\
\text { after Twist ends at year-end. }\end{array}$ \\
\hline & April 30, 2014 & None Given & None Given & $\begin{array}{l}\text { Agency MBS and } \\
\text { Long-Term } \\
\text { Treasuries }\end{array}$ & $\begin{array}{l}\text { Purchase Agency MBS at a pace of } \\
\$ 20 \text { b per month and long-term } \\
\text { Treasuries at a pace of } \$ 25 \mathrm{~b} \text { per month } \\
\text { after Twist ends at year-end. }\end{array}$ \\
\hline & June 18, 2014 & None Given & None Given & $\begin{array}{l}\text { Agency MBS and } \\
\text { Long-Term } \\
\text { Treasuries }\end{array}$ & $\begin{array}{l}\text { Purchase Agency MBS at a pace of } \\
\$ 15 \mathrm{~b} \text { per month and long-term } \\
\text { Treasuries at a pace of } \$ 20 \mathrm{~b} \text { per month } \\
\text { after Twist ends at year-end. }\end{array}$ \\
\hline & July 30, 2014 & None Given & None Given & $\begin{array}{l}\text { Agency MBS and } \\
\text { Long-Term } \\
\text { Treasuries }\end{array}$ & $\begin{array}{l}\text { Purchase Agency MBS at a pace of } \\
\$ 10 \mathrm{~b} \text { per month and long-term } \\
\text { Treasuries at a pace of } \$ 15 \mathrm{~b} \text { per month } \\
\text { after Twist ends at year-end. }\end{array}$ \\
\hline
\end{tabular}


October 29, 2014
Agency MBS and

Long-Term

Treasuries
Purchase Agency MBS at a pace of $\$ 5 \mathrm{~b}$ per month and long-term Treasuries at a pace of $\$ 10 \mathrm{~b}$ per month after Twist ends at year-end.

Issue revised Policy Normalization Principles, which suggest that the policy rate will be moved before reducing portfolio size.

No additional purchases of Agency MBS and long-term Treasuries; maintain balance sheet size through reinvestment (as previous).

Source: Federal Open Market Committee 
Table 3: Descriptive Statistics

This table presents descriptive statistics for the variables of interest over the study period 2005-2015. All variables are as defined in the text. Difference is the difference in means between agency MREITs and non-agency MREITs. Significance for a twosided t-test across Agency and Non-Agency MREITs is indicated as follows: ${ }^{* *} \mathrm{p}<0.01,{ }^{* *} \mathrm{p}<0.05,{ }^{*} \mathrm{p}<0.1$.

\begin{tabular}{|c|c|c|c|c|c|c|c|c|c|}
\hline Panel A: Agency MREITs & $\mathbf{N}$ & Mean & SD & P25 & Median & P75 & Min & Max & Difference \\
\hline Total Assets & 447 & 18.0000 & 25.5000 & 4.4600 & 8.6300 & 17.5000 & 0.1920 & 142.0000 & $13.6700 * * *$ \\
\hline Growth in Assets & 447 & 0.0888 & 0.2582 & -0.0263 & 0.0149 & 0.0972 & -0.3471 & 1.6464 & 0.0254 \\
\hline Agency Securities/Assets & 447 & 0.8364 & 0.1547 & 0.7290 & 0.9091 & 0.9608 & 0.4135 & 0.9960 & $0.7760 * * *$ \\
\hline Issued Equity & 447 & 0.2573 & 0.4376 & 0.0000 & 0.0000 & 1.0000 & 0.0000 & 1.0000 & $0.1222^{* * *}$ \\
\hline Amount Issued & 447 & 0.0112 & 0.0316 & 0.0000 & 0.0000 & 0.0004 & 0.0000 & 0.2004 & -0.0061 \\
\hline Repurchased Shares & 447 & 0.2215 & 0.4157 & 0.0000 & 0.0000 & 0.0000 & 0.0000 & 1.0000 & $0.1062 * * *$ \\
\hline Number Repurchased & 447 & 0.0039 & 0.0127 & 0.0000 & 0.0000 & 0.0000 & 0.0000 & 0.1275 & $0.0021 * * *$ \\
\hline Market-to-Book Value of Equity & 447 & 0.8897 & 0.1636 & 0.774 & 0.8857 & 0.9966 & 0.3208 & 1.4137 & $-0.0515^{* *}$ \\
\hline Equity/Assets & 447 & 0.1388 & 0.0509 & 0.1053 & 0.1247 & 0.1561 & 0.0617 & 0.3770 & $-0.1552^{* * *}$ \\
\hline Cash/Assets & 447 & 0.0208 & 0.0189 & 0.0073 & 0.0191 & 0.0297 & 0.0000 & 0.2201 & $-0.0185^{* * *}$ \\
\hline Repo Debt/Assets & 447 & 0.7831 & 0.0965 & 0.7387 & 0.8077 & 0.8545 & 0.3152 & 0.9147 & $0.6211^{* * *}$ \\
\hline Repo Debt (0-30 days)/Total Repo & 447 & 0.4661 & 0.3006 & 0.2636 & 0.4735 & 0.7232 & 0.0000 & 1.0000 & $0.2976^{* * *}$ \\
\hline Fixed-Rate/Agency Securities & 319 & 0.5762 & 0.3872 & 0.0030 & 0.7358 & 0.9095 & 0.0000 & 1.0000 & $0.4855^{* * *}$ \\
\hline Swaps/Total Liabilities & 400 & 0.4505 & 0.2254 & 0.3567 & 0.4542 & 0.5764 & 0.0000 & 1.2060 & $0.3127 * * *$ \\
\hline Swaps \& Swaptions/Total Liabilities & 400 & 0.4792 & 0.2492 & 0.3567 & 0.4629 & 0.6030 & 0.0000 & 1.2060 & $0.3414 * * *$ \\
\hline Panel B: Non-Agency MREITs & & & & & & & & & \\
\hline Variable & & & & & & & & & \\
\hline Total Assets & 555 & 4.3300 & 7.1700 & 0.6910 & 1.9700 & 5.3000 & 0.0050 & 57.5000 & \\
\hline Growth in Assets & 555 & 0.0634 & 0.2507 & -0.0286 & 0.0103 & 0.0916 & -0.5563 & 1.9771 & \\
\hline Agency Securities/Assets & 555 & 0.0604 & 0.1378 & 0.0000 & 0.0000 & 0.0386 & 0.0000 & 0.8453 & \\
\hline Issued Equity & 555 & 0.1351 & 0.3422 & 0.0000 & 0.0000 & 0.0000 & 0.0000 & 1.0000 & \\
\hline Amount Issued & 555 & 0.0173 & 0.1174 & 0.0000 & 0.0000 & 0.0000 & 0.0000 & 1.8069 & \\
\hline Repurchased Shares & 555 & 0.1153 & 0.3197 & 0.0000 & 0.0000 & 0.0000 & 0.0000 & 1.0000 & \\
\hline Number Repurchased & 555 & 0.0018 & 0.0096 & 0.0000 & 0.0000 & 0.0000 & 0.0000 & 0.1452 & \\
\hline Market-to-Book Value of Equity & 555 & 0.9412 & 0.4041 & 0.7361 & 0.9569 & 1.1644 & -0.3463 & 2.0508 & \\
\hline Equity/Assets & 555 & 0.2940 & 0.2523 & 0.0978 & 0.2197 & 0.4191 & -0.1007 & 0.9945 & \\
\hline Cash/Assets & 555 & 0.0393 & 0.0927 & 0.0066 & 0.0160 & 0.0384 & 0.0002 & 1.0000 & \\
\hline Repo Debt/Assets & 555 & 0.1620 & 0.2079 & 0.0000 & 0.0625 & 0.2664 & 0.0000 & 0.8864 & \\
\hline Repo Debt (0-30 days)/Total Repo & 555 & 0.1685 & 0.3279 & 0.0000 & 0.0000 & 0.0998 & 0.0000 & 1.0000 & \\
\hline Fixed-Rate/Agency Securities & 166 & 0.0907 & 0.2294 & 0.0000 & 0.0000 & 0.0000 & 0.0000 & 1.0000 & \\
\hline Swaps/Total Liabilities & 518 & 0.1378 & 0.2145 & 0.0000 & 0.0519 & 0.1938 & 0.0000 & 1.7574 & \\
\hline Swaps \& Swaptions/Total Liabilities & 518 & 0.1378 & 0.2145 & 0.0000 & 0.0519 & 0.1938 & 0.0000 & 1.7574 & \\
\hline Pnael C: Macro Environment & & & & & & & & & \\
\hline 3-Month CMT & 44 & 1.0250 & 1.7187 & 0.0300 & 0.0900 & 1.1500 & 0.0100 & 5.0800 & \\
\hline CMT Term Structure & 44 & 2.0040 & 1.0159 & 1.6100 & 2.1800 & 2.6700 & -0.5200 & 3.5800 & \\
\hline Option-Adjusted Spread & 44 & 0.4866 & 0.2911 & 0.2700 & 0.3800 & 0.5800 & 0.1100 & 1.4500 & \\
\hline Credit Spread & 44 & 2.7349 & 0.7816 & 2.2600 & 2.7500 & 3.0800 & 1.5900 & 5.8200 & \\
\hline Case-Shiller House Price Index & 44 & 0.0049 & 0.0301 & -0.0078 & 0.0066 & 0.0272 & -0.0696 & 0.0742 & \\
\hline Fed MBS Purchase Share & 44 & 0.2470 & 0.2473 & 0.0000 & 0.2383 & 0.4641 & 0.0000 & 0.8622 & \\
\hline Fed Treasury Purchase Share & 44 & 0.0993 & 0.0850 & 0.0364 & 0.0671 & 0.1912 & 0.0000 & 0.2815 & \\
\hline
\end{tabular}




\section{Table 4: Quarterly Asset Growth}

The table presents the panel regression results for Agency versus non-Agency MREIT asset growth (quarterly percentage change in the book value of assets) as a function of macroeconomic factors (level and slope of the term structure, option-adjusted mortgage spread, credit spread, growth in the Case-Shiller House Price index), firm characteristics (equity issuance, share repurchases, lagged firm size), as well as Federal Reserve purchase shares of Treasury Securities and Agency MBS. The study period is 2005-2015. All estimates are produced using OLS. Robust standard errors (clustered by firm) are reported in parentheses. Significance is indicated as follows: ${ }^{* *} \mathrm{p}<0.01{ }^{* *} \mathrm{p}<0.05{ }^{*} \mathrm{p}<0.1$.

\begin{tabular}{|c|c|c|c|c|}
\hline \multirow[b]{2}{*}{ VARIABLES } & $(1)$ & (2) & (3) & (4) \\
\hline & \multicolumn{4}{|c|}{ Asset Growth Asset Growth Asset Growth Asset Growth } \\
\hline \multirow[t]{2}{*}{ 3-Month CMT } & $-0.035^{*}$ & -0.031 & -0.035 & -0.036 \\
\hline & $(0.019)$ & $(0.019)$ & $(0.022)$ & $(0.022)$ \\
\hline \multirow[t]{2}{*}{ CMT Term Structure } & -0.013 & -0.012 & -0.021 & -0.022 \\
\hline & $(0.023)$ & $(0.023)$ & $(0.023)$ & $(0.023)$ \\
\hline \multirow[t]{2}{*}{ Option-Adjusted Spread } & $-0.074 *$ & $-0.068^{*}$ & -0.059 & -0.057 \\
\hline & $(0.039)$ & $(0.038)$ & $(0.040)$ & $(0.040)$ \\
\hline \multirow[t]{2}{*}{ Credit Spread } & -0.007 & -0.009 & -0.008 & -0.007 \\
\hline & $(0.015)$ & $(0.015)$ & $(0.016)$ & $(0.016)$ \\
\hline \multirow[t]{2}{*}{ Case-Shiller House Price Index } & 0.314 & 0.365 & 0.267 & 0.281 \\
\hline & $(0.317)$ & $(0.317)$ & $(0.298)$ & $(0.296)$ \\
\hline \multirow[t]{2}{*}{ Amount Issued } & $1.395^{* * *}$ & $1.382^{* * *}$ & $1.401 * * *$ & $1.413^{* * *}$ \\
\hline & $(0.180)$ & $(0.177)$ & $(0.181)$ & $(0.181)$ \\
\hline \multirow[t]{2}{*}{ Number Repurchased } & $-2.227 * * *$ & $-1.962 * * *$ & $-2.139 * * *$ & $-1.806 * * *$ \\
\hline & $(0.330)$ & $(0.317)$ & $(0.353)$ & $(0.298)$ \\
\hline \multirow[t]{2}{*}{ L.Firm Size } & $-0.017^{*}$ & $-0.017^{*}$ & $-0.017 *$ & $-0.018^{*}$ \\
\hline & $(0.009)$ & $(0.009)$ & $(0.009)$ & $(0.009)$ \\
\hline \multirow[t]{2}{*}{ Agency MREIT } & $0.065^{* *}$ & $0.124 * * *$ & $0.065^{* *}$ & $0.061 * *$ \\
\hline & $(0.028)$ & $(0.043)$ & $(0.028)$ & $(0.026)$ \\
\hline \multirow[t]{2}{*}{ Fed Treasury Purchase Share } & $0.478^{* *}$ & $0.473^{* *}$ & $0.512^{*}$ & $0.519^{*}$ \\
\hline & $(0.237)$ & $(0.235)$ & $(0.280)$ & $(0.279)$ \\
\hline \multirow[t]{2}{*}{ Fed MBS Purchase Share } & $-0.112^{* *}$ & -0.007 & & \\
\hline & $(0.046)$ & $(0.047)$ & & \\
\hline \multirow[t]{2}{*}{ Agency MREIT*Fed MBS Purchase Share } & & $-0.225^{* * *}$ & & \\
\hline & & $(0.081)$ & & \\
\hline \multirow[t]{2}{*}{ Fed MBS Purchase Share QE1 } & & & -0.049 & -0.077 \\
\hline & & & $(0.043)$ & $(0.056)$ \\
\hline \multirow[t]{2}{*}{ QE2 } & & & 0.026 & $-0.148^{* * *}$ \\
\hline & & & $(0.050)$ & $(0.051)$ \\
\hline \multirow[t]{2}{*}{ Fed MBS Purchase Share QE3 } & & & $-0.119 * *$ & -0.040 \\
\hline & & & $(0.047)$ & $(0.070)$ \\
\hline \multirow[t]{2}{*}{ Fed MBS Purchase Share Taper } & & & -0.031 & 0.074 \\
\hline & & & $(0.050)$ & $(0.069)$ \\
\hline \multirow[t]{2}{*}{ Agency MREIT*Fed MBS Purchase Share QE1 } & & & & 0.072 \\
\hline & & & & $(0.076)$ \\
\hline \multirow[t]{2}{*}{ Agency MREIT*QE2 } & & & & $0.350 * * *$ \\
\hline & & & & $(0.081)$ \\
\hline \multirow[t]{2}{*}{ Agency MREIT*Fed MBS Purchase Share QE3 } & & & & $-0.142^{* *}$ \\
\hline & & & & $(0.070)$ \\
\hline \multirow[t]{2}{*}{ Agency MREIT*Fed MBS Purchase Share Taper } & & & & $-0.185^{* *}$ \\
\hline & & & & $(0.092)$ \\
\hline \multirow[t]{2}{*}{ Constant } & $0.385^{* *}$ & $0.350^{* *}$ & $0.376^{* *}$ & $0.392^{* *}$ \\
\hline & $(0.149)$ & $(0.147)$ & $(0.149)$ & $(0.150)$ \\
\hline Observations & 1,002 & 1,002 & 1,002 & 1,002 \\
\hline R-squared & 0.326 & 0.337 & 0.327 & 0.366 \\
\hline Number of Firm Clusters & 50 & 50 & 50 & 50 \\
\hline
\end{tabular}




\section{Table 5: Quarterly Equity Issuance}

The table presents panel regression results for Agency versus Non-Agency MREIT as a function of quarterly equity issuance (a binary issuance indicator) as a function of macroeconomic factors (level and slope of the term structure, option-adjusted mortgage spread, credit spread, growth in the Case-Shiller House Price index), firm characteristics (market-to-book ratio, lagged firm size), as well as Federal Reserve purchase shares of Treasury Securities and Agency MBS. The study period is 2005-2015. All estimates are produced using OLS. Robust standard errors (clustered by firm) are reported in parentheses. Significance is indicated as follows: ${ }^{* * *} \mathrm{p}<0.01 ;{ }^{* *} \mathrm{p}<0.05 ;{ }^{*} \mathrm{p}<0.1$.
(1)
(2)
(3)
(4)

VARIABLES

Equity Issuance Equity Issuance Equity Issuance Equity Issuance

3-Month CMT

CMT Term Structure

Option-Adjusted Spread

Credit Spread

Case-Shiller Index

L.Market-to-Book Value of Equity

L.Firm Size

Agency MREIT

Fed Treasury Purchase Share

Fed MBS Purchase Share

Agency MREIT*Fed MBS Purchase Share

Fed MBS Purchase Share QE1

QE2

Fed MBS Purchase Share QE3

Fed MBS Purchase Share Taper

Agency MREIT*Fed MBS Purchase Share QE1

Agency MREIT*QE2

Agency MREIT*Fed MBS Purchase Share QE3

Agency MREIT*Fed MBS Purchase Share Taper

Constant

Observations

R-squared

Number of Firm Clusters

\begin{tabular}{|c|c|c|c|}
\hline$-0.083^{* *}$ & $-0.073^{* *}$ & $-0.086 * * *$ & $-0.079 * * *$ \\
\hline$(0.031)$ & $(0.029)$ & $(0.030)$ & $(0.029)$ \\
\hline 0.037 & 0.039 & -0.002 & 0.001 \\
\hline$(0.034)$ & $(0.034)$ & $(0.029)$ & $(0.028)$ \\
\hline 0.056 & 0.071 & 0.079 & 0.085 \\
\hline$(0.066)$ & $(0.065)$ & $(0.076)$ & $(0.075)$ \\
\hline 0.035 & 0.029 & 0.035 & 0.035 \\
\hline$(0.036)$ & $(0.036)$ & $(0.035)$ & $(0.035)$ \\
\hline 0.030 & 0.134 & 0.019 & 0.072 \\
\hline$(0.505)$ & $(0.508)$ & $(0.514)$ & $(0.514)$ \\
\hline $0.222 * * *$ & $0.242^{* * *}$ & $0.232 * * *$ & $0.191 * * *$ \\
\hline$(0.041)$ & $(0.045)$ & $(0.042)$ & $(0.042)$ \\
\hline-0.001 & 0.000 & -0.001 & 0.001 \\
\hline$(0.012)$ & $(0.012)$ & $(0.013)$ & $(0.012)$ \\
\hline $0.111^{* *}$ & $0.280^{* * *}$ & $0.112^{* *}$ & $0.173^{* * *}$ \\
\hline$(0.053)$ & $(0.058)$ & $(0.053)$ & $(0.052)$ \\
\hline $1.707 * * *$ & $1.655^{* * *}$ & $1.503^{* * *}$ & $1.527 * * *$ \\
\hline$(0.383)$ & $(0.381)$ & $(0.477)$ & $(0.481)$ \\
\hline-0.088 & $0.212^{* *}$ & & \\
\hline \multirow[t]{19}{*}{$(0.102)$} & $(0.087)$ & & \\
\hline & $-0.636 * * *$ & & \\
\hline & $(0.138)$ & & \\
\hline & & 0.100 & 0.050 \\
\hline & & $(0.108)$ & $(0.079)$ \\
\hline & & $0.113^{*}$ & -0.017 \\
\hline & & $(0.067)$ & $(0.083)$ \\
\hline & & -0.067 & $0.238^{*}$ \\
\hline & & $(0.089)$ & $(0.138)$ \\
\hline & & 0.023 & $0.390 * *$ \\
\hline & & $(0.115)$ & $(0.151)$ \\
\hline & & & 0.113 \\
\hline & & & $(0.238)$ \\
\hline & & & $0.257^{* *}$ \\
\hline & & & $(0.100)$ \\
\hline & & & $-0.562^{* * *}$ \\
\hline & & & $(0.157)$ \\
\hline & & & $-0.686 * * *$ \\
\hline & & & $(0.187)$ \\
\hline-0.317 & $-0.408^{*}$ & -0.258 & -0.302 \\
\hline$(0.217)$ & $(0.215)$ & $(0.200)$ & $(0.190)$ \\
\hline 1,002 & 1,002 & 1,002 & 1,002 \\
\hline 0.128 & 0.164 & 0.130 & 0.175 \\
\hline 50 & 50 & 50 & 50 \\
\hline
\end{tabular}


Table 6: Quarterly Equity to Total Assets Ratio

The table presents the panel regression results for Agency versus Non-Agency MREIT equity to total assets ratios as a function of macroeconomic factors (level and slope of the term structure, option-adjusted mortgage spread, credit spread, growth in the Case-Shiller House Price index), firm and capital structure characteristics, as well as Federal Reserve purchase shares of Treasury Securities and Agency MBS. The study period is 2005-2015. All estimates are produced using OLS. Robust standard errors (clustered by firm) are reported in parentheses. Significance is indicated as follows: ${ }^{* * *} \mathrm{p}<0.01 ;{ }^{* *} \mathrm{p}<0.05$; $^{*} \mathrm{p}<0.1$.

(1) (2) (3) (4)

VARIABLES

Equity/Assets Equity/Assets Equity/Assets Equity/Assets

3-Month CMT

CMT Term Structure

Option-Adjusted Spread

Credit Spread

Case-Shiller Index

L.Repo (0-30)/Total Repo

L.Cash/Assets

L.Firm Size

Agency MREIT

Fed Treasury Purchase Share

Fed MBS Purchase Share

Agency MREIT*Fed MBS Purchase Share

Fed MBS Purchase Share QE1

QE2

Fed MBS Purchase Share QE3

Fed MBS Purchase Share Taper

Agency MREIT*Fed MBS Purchase Share QE1

Agency MREIT*QE2

Agency MREIT*Fed MBS Purchase Share QE3

Agency MREIT*Fed MBS Purchase Share Taper

Constant

Observations

R-squared

Number of Firm Clusters

$\begin{array}{cc}-0.049 * * & -0.048^{* *} \\ (0.022) & (0.022) \\ -0.033^{*} & -0.033^{*} \\ (0.018) & (0.018) \\ -0.031^{*} & -0.030^{*} \\ (0.018) & (0.017) \\ -0.018^{* *} & -0.018^{* *} \\ (0.007) & (0.007) \\ 0.058 & 0.067 \\ (0.155) & (0.152) \\ -0.030 & -0.031 \\ (0.033) & (0.033) \\ 0.830 * * * & 0.828 * * * \\ (0.088) & (0.089) \\ -0.038 * * * & -0.038 * * * \\ (0.007) & (0.007) \\ -0.081 * * & -0.068 * \\ (0.039) & (0.038) \\ 0.060 & 0.057 \\ (0.215) & (0.216) \\ -0.019 & 0.003 \\ (0.026) & (0.043) \\ & -0.046 \\ & (0.050)\end{array}$

\begin{tabular}{|c|c|c|c|}
\hline & & $-0.071 *$ & $-0.117 *$ \\
\hline & & $(0.037)$ & $(0.068)$ \\
\hline & & 0.025 & $0.059 *$ \\
\hline & & $(0.018)$ & $(0.031)$ \\
\hline & & $0.061 * *$ & $0.157 * * *$ \\
\hline & & $(0.027)$ & $(0.055)$ \\
\hline & & 0.038 & 0.092 \\
\hline & & $(0.029)$ & $(0.060)$ \\
\hline & & & 0.110 \\
\hline & & & $(0.086)$ \\
\hline & & & -0.066 \\
\hline & & & $(0.049)$ \\
\hline & & & $-0.175^{* *}$ \\
\hline & & & $(0.068)$ \\
\hline & & & -0.101 \\
\hline & & & $(0.068)$ \\
\hline $0.988^{* * *}$ & $0.981 * * *$ & $0.927^{* * *}$ & $0.901 * * *$ \\
\hline$(0.157)$ & $(0.157)$ & $(0.146)$ & $(0.144)$ \\
\hline 1,002 & 1,002 & 1,002 & 1,002 \\
\hline 0.443 & 0.444 & 0.451 & 0.463 \\
\hline 50 & 50 & 50 & 50 \\
\hline
\end{tabular}

$\begin{array}{ll}-0.034 & -0.033\end{array}$

$(0.021) \quad(0.020)$

$-0.021 \quad-0.021$

$(0.017) \quad(0.017)$

$-0.039 * * \quad-0.035^{*}$

(0.018) (0.018)

$-0.006 \quad-0.007$

(0.005) (0.005)

$0.094 \quad 0.104$

(0.171) (0.172)

$-0.031 \quad-0.041$

(0.034) (0.037)

$0.842^{* * *} \quad 0.858^{* * *}$

(0.088) (0.090)

-0.039 *** $\quad-0.038^{* * *}$

(0.008) (0.008)

$-0.080 * * \quad-0.060^{*}$

$(0.040) \quad(0.035)$

$0.000 \quad-0.002$

$(0.224) \quad(0.225)$

(0.043)

$(0.050)$ 


\section{Table 7: Quarterly Repo to Total Assets Ratio}

The table presents the panel regression results for Agency versus Non-Agency MREIT repurchase agreements to total assets ratios as a function of macroeconomic factors (level and slope of the term structure, option-adjusted mortgage spread, credit spread, growth in the Case-Shiller House Price index), firm and capital structure characteristics, as well as Federal Reserve purchase shares of Treasury Securities and Agency MBS. The study period is 2005-2015. All estimates are produced using OLS. Robust standard errors (clustered by firm) are reported in parentheses. Significance is indicated as follows: ${ }^{* * *} \mathrm{p}<0.01 ;{ }^{* *} \mathrm{p}<0.05$; $* \mathrm{p}<0.1$.

\begin{tabular}{|c|c|c|c|c|}
\hline VARIABLES & $\begin{array}{c}(1) \\
\text { Repo/Assets } \\
\end{array}$ & $\begin{array}{c}(2) \\
\text { Repo/Assets }\end{array}$ & $\begin{array}{c}(3) \\
\text { Repo/Assets }\end{array}$ & $\begin{array}{c}(4) \\
\text { Repo/Assets } \\
\end{array}$ \\
\hline 3-Month CMT & $\begin{array}{c}0.012 \\
(0.015)\end{array}$ & $\begin{array}{c}0.013 \\
(0.015)\end{array}$ & $\begin{array}{c}0.019 \\
(0.013)\end{array}$ & $\begin{array}{c}0.020 \\
(0.013)\end{array}$ \\
\hline CMT Term Structure & $\begin{array}{c}0.000 \\
(0.013)\end{array}$ & $\begin{array}{c}0.000 \\
(0.013)\end{array}$ & $\begin{array}{c}0.010 \\
(0.013)\end{array}$ & $\begin{array}{c}0.010 \\
(0.013)\end{array}$ \\
\hline Option-Adjusted Spread & $\begin{array}{c}0.032 \\
(0.020)\end{array}$ & $\begin{array}{l}0.034 * \\
(0.020)\end{array}$ & $\begin{array}{c}0.024 \\
(0.021)\end{array}$ & $\begin{array}{c}0.025 \\
(0.021)\end{array}$ \\
\hline Credit Spread & $\begin{array}{l}-0.012 \\
(0.011)\end{array}$ & $\begin{array}{l}-0.013 \\
(0.011)\end{array}$ & $\begin{array}{l}-0.004 \\
(0.008)\end{array}$ & $\begin{array}{l}-0.004 \\
(0.008)\end{array}$ \\
\hline Case-Shiller Index & $\begin{array}{l}-0.108 \\
(0.171)\end{array}$ & $\begin{array}{l}-0.093 \\
(0.167)\end{array}$ & $\begin{array}{l}-0.018 \\
(0.140)\end{array}$ & $\begin{array}{l}-0.012 \\
(0.139)\end{array}$ \\
\hline L.Cash/Assets & $\begin{array}{c}-0.198 * * * \\
(0.066)\end{array}$ & $\begin{array}{c}-0.201 * * * \\
(0.067)\end{array}$ & $\begin{array}{c}-0.188 * * * \\
(0.064)\end{array}$ & $\begin{array}{c}-0.176^{* * * *} \\
(0.062)\end{array}$ \\
\hline L.Firm Size & $\begin{array}{c}0.020 \\
(0.012)\end{array}$ & $\begin{array}{l}0.020^{*} \\
(0.012)\end{array}$ & $\begin{array}{c}0.019 \\
(0.012)\end{array}$ & $\begin{array}{c}0.019 \\
(0.012)\end{array}$ \\
\hline Agency MREIT & $\begin{array}{c}0.595^{* * *} \\
(0.045)\end{array}$ & $\begin{array}{c}0.615^{* * *} \\
(0.045)\end{array}$ & $\begin{array}{c}0.595^{* * *} \\
(0.045)\end{array}$ & $\begin{array}{c}0.605^{* * *} \\
(0.043)\end{array}$ \\
\hline Fed Treasury Purchase Share & $\begin{array}{l}-0.089 \\
(0.132)\end{array}$ & $\begin{array}{l}-0.094 \\
(0.133)\end{array}$ & $\begin{array}{l}-0.118 \\
(0.168)\end{array}$ & $\begin{array}{l}-0.120 \\
(0.168)\end{array}$ \\
\hline Fed MBS Purchase Share & $\begin{array}{c}0.050 \\
(0.031)\end{array}$ & $\begin{array}{c}0.087 \\
(0.058)\end{array}$ & & \\
\hline Agency MREIT*Fed MBS Purchase Share & & $\begin{array}{l}-0.079 \\
(0.077)\end{array}$ & & \\
\hline Fed MBS Purchase Share QE1 & & & $\begin{array}{l}-0.023 \\
(0.033)\end{array}$ & $\begin{array}{l}-0.053 \\
(0.048)\end{array}$ \\
\hline QE2 & & & $\begin{array}{l}-0.001 \\
(0.025)\end{array}$ & $\begin{array}{l}-0.014 \\
(0.033)\end{array}$ \\
\hline Fed MBS Purchase Share QE3 & & & $\begin{array}{c}0.067 \\
(0.041)\end{array}$ & $\begin{array}{c}0.104 \\
(0.086)\end{array}$ \\
\hline Fed MBS Purchase Share Taper & & & $\begin{array}{l}0.072 * \\
(0.037)\end{array}$ & $\begin{array}{l}0.159 * \\
(0.083)\end{array}$ \\
\hline Agency MREIT*Fed MBS Purchase Share QE1 & & & & $\begin{array}{c}0.072 \\
(0.055)\end{array}$ \\
\hline Agency MREIT*QE2 & & & & $\begin{array}{c}0.029 \\
(0.034)\end{array}$ \\
\hline Agency MREIT*Fed MBS Purchase Share QE3 & & & & $\begin{array}{l}-0.067 \\
(0.098)\end{array}$ \\
\hline Agency MREIT*Fed MBS Purchase Share Taper & & & & $\begin{array}{l}-0.160 \\
(0.100)\end{array}$ \\
\hline Constant & $\begin{array}{l}-0.114 \\
(0.184)\end{array}$ & $\begin{array}{l}-0.124 \\
(0.182)\end{array}$ & $\begin{array}{l}-0.148 \\
(0.177)\end{array}$ & $\begin{array}{l}-0.154 \\
(0.176)\end{array}$ \\
\hline Observations & 1,002 & 1,002 & 1,002 & 1,002 \\
\hline R-squared & 0.799 & 0.799 & 0.800 & 0.802 \\
\hline Number of Firm Clusters & 50 & 50 & 50 & 50 \\
\hline
\end{tabular}




\section{Table 8: Quarterly Repo (0-30 days) to Total Repo Ratio}

The table presents the panel regression results for Agency versus Non-Agency MREIT use of short-term repo debt (repo (0-30) to total repo debt), as a function of macroeconomic factors (level and slope of the term structure, option-adjusted mortgage spread, credit spread, growth in the Case-Shiller House Price index), firm and capital structure characteristics, as well as Federal Reserve purchase shares of Treasury Securities and Agency MBS. The study period is 2005-2015. All estimates are produced using OLS. Robust standard errors (clustered by firm) are reported in parentheses. Significance is indicated as follows: *** $\mathrm{p}<0.01 ; * * \mathrm{p}<0.05 ; * \mathrm{p}<0.1$.

\begin{tabular}{|c|c|c|c|c|}
\hline VARIABLES & $\begin{array}{c}(1) \\
\text { Repo }(0-30) / \operatorname{Repo} \\
\end{array}$ & $\begin{array}{c}(2) \\
\operatorname{Repo}(0-30) / \operatorname{Repo} \\
\end{array}$ & $\begin{array}{c}(3) \\
\operatorname{Repo}(0-30) / \operatorname{Repo} \\
\end{array}$ & $\begin{array}{c}(4) \\
\text { Repo }(0-30) / \operatorname{Repo} \\
\end{array}$ \\
\hline 3-Month CMT & $\begin{array}{l}-0.033 \\
(0.040)\end{array}$ & $\begin{array}{l}-0.031 \\
(0.041)\end{array}$ & $\begin{array}{l}-0.029 \\
(0.034)\end{array}$ & $\begin{array}{l}-0.028 \\
(0.035)\end{array}$ \\
\hline CMT Term Structure & $\begin{array}{l}-0.008 \\
(0.040)\end{array}$ & $\begin{array}{l}-0.008 \\
(0.040)\end{array}$ & $\begin{array}{c}0.001 \\
(0.032)\end{array}$ & $\begin{array}{l}-0.001 \\
(0.033)\end{array}$ \\
\hline Option-Adjusted Spread & $\begin{array}{c}0.000 \\
(0.040)\end{array}$ & $\begin{array}{c}0.003 \\
(0.041)\end{array}$ & $\begin{array}{l}-0.021 \\
(0.039)\end{array}$ & $\begin{array}{l}-0.017 \\
(0.040)\end{array}$ \\
\hline Credit Spread & $\begin{array}{c}0.017 \\
(0.023)\end{array}$ & $\begin{array}{c}0.015 \\
(0.023)\end{array}$ & $\begin{array}{c}0.024 \\
(0.019)\end{array}$ & $\begin{array}{c}0.023 \\
(0.019)\end{array}$ \\
\hline Case-Shiller Index & $\begin{array}{l}-0.330 \\
(0.286)\end{array}$ & $\begin{array}{l}-0.303 \\
(0.295)\end{array}$ & $\begin{array}{l}-0.305 \\
(0.250)\end{array}$ & $\begin{array}{l}-0.284 \\
(0.259)\end{array}$ \\
\hline L.Equity/Assets & $\begin{array}{l}-0.180 \\
(0.128)\end{array}$ & $\begin{array}{l}-0.185 \\
(0.127)\end{array}$ & $\begin{array}{l}-0.187 \\
(0.133)\end{array}$ & $\begin{array}{l}-0.227 \\
(0.142)\end{array}$ \\
\hline L.Cash/Assets & $\begin{array}{c}0.083 \\
(0.153)\end{array}$ & $\begin{array}{c}0.082 \\
(0.153)\end{array}$ & $\begin{array}{c}0.090 \\
(0.161)\end{array}$ & $\begin{array}{c}0.163 \\
(0.179)\end{array}$ \\
\hline L.Firm Size & $\begin{array}{c}0.026 \\
(0.016)\end{array}$ & $\begin{array}{c}0.027 \\
(0.016)\end{array}$ & $\begin{array}{c}0.026 \\
(0.017)\end{array}$ & $\begin{array}{c}0.026 \\
(0.016)\end{array}$ \\
\hline Agency MREIT & $\begin{array}{l}0.215^{* *} \\
(0.089)\end{array}$ & $\begin{array}{c}0.254^{* * *} \\
(0.088)\end{array}$ & $\begin{array}{c}0.214^{* *} \\
(0.089)\end{array}$ & $\begin{array}{c}0.243^{* * *} \\
(0.086)\end{array}$ \\
\hline Fed Treasury Purchase Share & $\begin{array}{c}0.374 \\
(0.278)\end{array}$ & $\begin{array}{c}0.365 \\
(0.279)\end{array}$ & $\begin{array}{c}0.363 \\
(0.310)\end{array}$ & $\begin{array}{c}0.352 \\
(0.311)\end{array}$ \\
\hline Fed MBS Purchase Share & $\begin{array}{l}0.090^{*} \\
(0.051)\end{array}$ & $\begin{array}{l}0.162 * \\
(0.094)\end{array}$ & & \\
\hline Agency MREIT*Fed MBS Purchase Share & & $\begin{array}{l}-0.153 \\
(0.152)\end{array}$ & & \\
\hline Fed MBS Purchase Share QE1 & & & $\begin{array}{c}0.026 \\
(0.079)\end{array}$ & $\begin{array}{l}-0.089 \\
(0.129)\end{array}$ \\
\hline QE2 & & & $\begin{array}{l}-0.020 \\
(0.041)\end{array}$ & $\begin{array}{l}-0.013 \\
(0.058)\end{array}$ \\
\hline Fed MBS Purchase Share QE3 & & & $\begin{array}{l}0.131 * \\
(0.072)\end{array}$ & $\begin{array}{c}0.378^{* *} \\
(0.153)\end{array}$ \\
\hline Fed MBS Purchase Share Taper & & & $\begin{array}{c}0.050 \\
(0.054)\end{array}$ & $\begin{array}{c}0.167 \\
(0.109)\end{array}$ \\
\hline Agency MREIT*Fed MBS Purchase Share QE1 & & & & $\begin{array}{l}0.273^{*} \\
(0.151)\end{array}$ \\
\hline Agency MREIT*QE2 & & & & $\begin{array}{l}-0.004 \\
(0.078)\end{array}$ \\
\hline Agency MREIT*Fed MBS Purchase Share QE3 & & & & $\begin{array}{c}-0.447^{* *} \\
(0.206)\end{array}$ \\
\hline Agency MREIT*Fed MBS Purchase Share Taper & & & & $\begin{array}{l}-0.213 \\
(0.151)\end{array}$ \\
\hline Constant & $\begin{array}{l}-0.205 \\
(0.333)\end{array}$ & $\begin{array}{l}-0.220 \\
(0.333)\end{array}$ & $\begin{array}{l}-0.217 \\
(0.308)\end{array}$ & $\begin{array}{l}-0.216 \\
(0.308)\end{array}$ \\
\hline Observations & 1,002 & 1,002 & 1,002 & 1,002 \\
\hline R-squared & 0.231 & 0.234 & 0.233 & 0.255 \\
\hline Number of Firm Clusters & 50 & 50 & 50 & 50 \\
\hline
\end{tabular}




\section{Table 9: Quarterly Cash to Total Assets Ratio}

The table presents the panel regression results for Agency MREIT cash to total assets ratios, as a function of macroeconomic factors (level and slope of the term structure, option-adjusted mortgage spread, credit spread, growth in the Case-Shiller House Price index), firm and capital structure characteristics, as well as Federal Reserve purchase shares of Treasury Securities and Agency MBS. The study period is 2005-2015. All estimates are produced using OLS. Robust standard errors (clustered by firm) are reported in parentheses. Significance is indicated as follows: ${ }^{* * *} \mathrm{p}<0.01 ;{ }^{* *} \mathrm{p}<0.05 ;{ }^{*} \mathrm{p}<0.1$.

\begin{tabular}{|c|c|c|c|c|}
\hline VARIABLES & $\begin{array}{c}(1) \\
\text { Cash/Assets } \\
\end{array}$ & $\begin{array}{c}(2) \\
\text { Cash/Assets }\end{array}$ & $\begin{array}{c}(3) \\
\text { Cash/Assets }\end{array}$ & $\begin{array}{c}(4) \\
\text { Cash/Assets }\end{array}$ \\
\hline 3-Month CMT & $\begin{array}{c}0.003 \\
(0.004)\end{array}$ & $\begin{array}{c}0.003 \\
(0.004)\end{array}$ & $\begin{array}{c}0.001 \\
(0.003)\end{array}$ & $\begin{array}{c}0.001 \\
(0.003)\end{array}$ \\
\hline CMT Term Structure & $\begin{array}{c}0.004 \\
(0.005)\end{array}$ & $\begin{array}{c}0.004 \\
(0.005)\end{array}$ & $\begin{array}{c}0.003 \\
(0.004)\end{array}$ & $\begin{array}{c}0.003 \\
(0.004)\end{array}$ \\
\hline Option-Adjusted Spread & $\begin{array}{l}-0.011 \\
(0.007)\end{array}$ & $\begin{array}{l}-0.011 \\
(0.007)\end{array}$ & $\begin{array}{l}-0.011 \\
(0.007)\end{array}$ & $\begin{array}{l}-0.011 \\
(0.007)\end{array}$ \\
\hline Credit Spread & $\begin{array}{c}0.003 \\
(0.003)\end{array}$ & $\begin{array}{c}0.003 \\
(0.003)\end{array}$ & $\begin{array}{c}0.001 \\
(0.002)\end{array}$ & $\begin{array}{c}0.001 \\
(0.002)\end{array}$ \\
\hline Case-Shiller Index & $\begin{array}{l}-0.007 \\
(0.036)\end{array}$ & $\begin{array}{l}-0.008 \\
(0.036)\end{array}$ & $\begin{array}{l}-0.026 \\
(0.044)\end{array}$ & $\begin{array}{l}-0.027 \\
(0.043)\end{array}$ \\
\hline L.Equity/Assets & $\begin{array}{c}0.105^{* * *} \\
(0.037)\end{array}$ & $\begin{array}{c}0.105^{* * *} \\
(0.037)\end{array}$ & $\begin{array}{c}0.106^{* * *} \\
(0.038)\end{array}$ & $\begin{array}{c}0.109 * * * \\
(0.039)\end{array}$ \\
\hline L.Repo (0-30)/Total Repo & $\begin{array}{c}0.004 \\
(0.005)\end{array}$ & $\begin{array}{c}0.004 \\
(0.005)\end{array}$ & $\begin{array}{c}0.004 \\
(0.005)\end{array}$ & $\begin{array}{c}0.006 \\
(0.006)\end{array}$ \\
\hline L.Firm Size & $\begin{array}{l}-0.002 \\
(0.002)\end{array}$ & $\begin{array}{l}-0.002 \\
(0.002)\end{array}$ & $\begin{array}{l}-0.002 \\
(0.002)\end{array}$ & $\begin{array}{l}-0.002 \\
(0.002)\end{array}$ \\
\hline Agency MREIT & $\begin{array}{c}0.003 \\
(0.005)\end{array}$ & $\begin{array}{c}0.002 \\
(0.006)\end{array}$ & $\begin{array}{c}0.003 \\
(0.005)\end{array}$ & $\begin{array}{l}-0.001 \\
(0.005)\end{array}$ \\
\hline Fed Treasury Purchase Share & $\begin{array}{l}-0.035 \\
(0.032)\end{array}$ & $\begin{array}{l}-0.035 \\
(0.032)\end{array}$ & $\begin{array}{l}-0.020 \\
(0.046)\end{array}$ & $\begin{array}{l}-0.019 \\
(0.046)\end{array}$ \\
\hline Fed MBS Purchase Share & $\begin{array}{c}0.003 \\
(0.006)\end{array}$ & $\begin{array}{c}0.001 \\
(0.010)\end{array}$ & & \\
\hline Agency MREIT*Fed MBS Purchase Share & & $\begin{array}{c}0.004 \\
(0.011)\end{array}$ & & \\
\hline Fed MBS Purchase Share QE1 & & & $\begin{array}{c}0.008 \\
(0.013)\end{array}$ & $\begin{array}{c}0.016 \\
(0.028)\end{array}$ \\
\hline QE2 & & & $\begin{array}{l}-0.008 \\
(0.010)\end{array}$ & $\begin{array}{l}-0.015 \\
(0.013)\end{array}$ \\
\hline Fed MBS Purchase Share QE3 & & & $\begin{array}{l}-0.005 \\
(0.007)\end{array}$ & $\begin{array}{l}-0.019 \\
(0.016)\end{array}$ \\
\hline Fed MBS Purchase Share Taper & & & $\begin{array}{c}-0.017 * \\
(0.010)\end{array}$ & $\begin{array}{c}-0.036 * * \\
(0.018)\end{array}$ \\
\hline Agency MREIT*Fed MBS Purchase Share QE1 & & & & $\begin{array}{l}-0.018 \\
(0.036)\end{array}$ \\
\hline Agency MREIT*QE2 & & & & $\begin{array}{c}0.013 \\
(0.011)\end{array}$ \\
\hline Agency MREIT*Fed MBS Purchase Share QE3 & & & & $\begin{array}{c}0.026 \\
(0.017)\end{array}$ \\
\hline Agency MREIT*Fed MBS Purchase Share Taper & & & & $\begin{array}{c}0.036 * * \\
(0.018)\end{array}$ \\
\hline Constant & $\begin{array}{c}0.019 \\
(0.039)\end{array}$ & $\begin{array}{c}0.019 \\
(0.040)\end{array}$ & $\begin{array}{c}0.025 \\
(0.036)\end{array}$ & $\begin{array}{c}0.027 \\
(0.038)\end{array}$ \\
\hline Observations & 1,002 & 1,002 & 1,002 & 1,002 \\
\hline R-squared & 0.230 & 0.230 & 0.235 & 0.242 \\
\hline Number of Firm Clusters & 50 & 50 & 50 & 50 \\
\hline
\end{tabular}


Table 10: Agency MREIT Fixed-Rate to Total Agency MBS Ratio

The table presents the panel regression results for Agency MREIT investment in fixed-rate agency MBS (measured as the ratio of fixed-rate agency securities to total agency securities), as a function of macroeconomic factors (level and slope of the term structure, option-adjusted mortgage spread, credit spread, growth in the Case-Shiller House Price index), firm and capital structure characteristics, as well as Federal Reserve purchase shares of Treasury Securities and Agency MBS. The study period is 2005-2015. All estimates are produced using OLS. Robust standard errors (clustered by firm) are reported in parentheses. Significance is indicated as follows: ${ }^{* * *} \mathrm{p}<0.01 ; * * \mathrm{p}<0.05 ;{ }^{*} \mathrm{p}<0.1$.

\begin{tabular}{|c|c|c|c|c|}
\hline & (1) & $(2)$ & (3) & (4) \\
\hline VARIABLES & Fixed/Agency & Fixed/Agency & Fixed/Agency & Fixed/Agency \\
\hline 3-Month CMT & $\begin{array}{c}-0.159 * * * \\
(0.040)\end{array}$ & $\begin{array}{c}-0.159 * * * \\
(0.042)\end{array}$ & $\begin{array}{c}-0.122 * * * \\
(0.036)\end{array}$ & $\begin{array}{c}-0.120^{* * *} \\
(0.038)\end{array}$ \\
\hline CMT Term Structure & $\begin{array}{c}-0.143^{* * *} \\
(0.044)\end{array}$ & $\begin{array}{c}-0.143^{* * *} \\
(0.044)\end{array}$ & $\begin{array}{c}-0.113 * * * \\
(0.037)\end{array}$ & $\begin{array}{c}-0.113 * * * \\
(0.039)\end{array}$ \\
\hline Option-Adjusted Spread & $\begin{array}{l}-0.044 \\
(0.052)\end{array}$ & $\begin{array}{l}-0.044 \\
(0.052)\end{array}$ & $\begin{array}{l}-0.075 \\
(0.050)\end{array}$ & $\begin{array}{l}-0.075 \\
(0.049)\end{array}$ \\
\hline Credit Spread & $\begin{array}{l}-0.039 \\
(0.026)\end{array}$ & $\begin{array}{l}-0.040 \\
(0.026)\end{array}$ & $\begin{array}{l}-0.005 \\
(0.020)\end{array}$ & $\begin{array}{l}-0.003 \\
(0.020)\end{array}$ \\
\hline Case-Shiller Index & $\begin{array}{c}0.438 \\
(0.412)\end{array}$ & $\begin{array}{c}0.443 \\
(0.378)\end{array}$ & $\begin{array}{l}0.723^{*} \\
(0.409)\end{array}$ & $\begin{array}{c}0.778^{*} \\
(0.399)\end{array}$ \\
\hline L.Equity/Assets & $\begin{array}{l}-0.671 \\
(0.456)\end{array}$ & $\begin{array}{l}-0.675 \\
(0.457)\end{array}$ & $\begin{array}{l}-0.678 \\
(0.462)\end{array}$ & $\begin{array}{l}-0.710 \\
(0.474)\end{array}$ \\
\hline L.Repo (0-30)/Repo & $\begin{array}{l}-0.265 \\
(0.178)\end{array}$ & $\begin{array}{l}-0.267 \\
(0.180)\end{array}$ & $\begin{array}{l}-0.262 \\
(0.177)\end{array}$ & $\begin{array}{l}-0.275 \\
(0.177)\end{array}$ \\
\hline L.Cash/Assets & $\begin{array}{l}-0.573 \\
(1.678)\end{array}$ & $\begin{array}{l}-0.565 \\
(1.677)\end{array}$ & $\begin{array}{l}-0.680 \\
(1.623)\end{array}$ & $\begin{array}{l}-0.732 \\
(1.615)\end{array}$ \\
\hline L.Firm Size & $\begin{array}{c}0.015 \\
(0.035)\end{array}$ & $\begin{array}{c}0.015 \\
(0.035)\end{array}$ & $\begin{array}{c}0.012 \\
(0.035)\end{array}$ & $\begin{array}{c}0.013 \\
(0.035)\end{array}$ \\
\hline Agency MREIT & $\begin{array}{c}0.373 * * * \\
(0.103)\end{array}$ & $\begin{array}{c}0.376^{* * *} \\
(0.105)\end{array}$ & $\begin{array}{c}0.374^{* * *} \\
(0.102)\end{array}$ & $\begin{array}{c}0.394^{* * *} \\
(0.102)\end{array}$ \\
\hline Fed Treasury Purchase Share & $\begin{array}{c}0.040 \\
(0.338)\end{array}$ & $\begin{array}{c}0.039 \\
(0.342)\end{array}$ & $\begin{array}{l}-0.240 \\
(0.418)\end{array}$ & $\begin{array}{l}-0.244 \\
(0.422)\end{array}$ \\
\hline Fed MBS Purchase Share & $\begin{array}{c}0.114^{*} \\
(0.057)\end{array}$ & $\begin{array}{c}0.125 \\
(0.153)\end{array}$ & & \\
\hline Agency MREIT*Fed MBS Purchase Share & & $\begin{array}{l}-0.016 \\
(0.202)\end{array}$ & & \\
\hline Fed MBS Purchase Share QE1 & & & $\begin{array}{l}-0.118 \\
(0.079)\end{array}$ & $\begin{array}{c}0.018 \\
(0.249)\end{array}$ \\
\hline QE2 & & & $\begin{array}{c}0.061 \\
(0.049)\end{array}$ & $\begin{array}{l}-0.021 \\
(0.092)\end{array}$ \\
\hline Fed MBS Purchase Share QE3 & & & $\begin{array}{c}0.274^{* * *} \\
(0.080)\end{array}$ & $\begin{array}{c}0.513^{* *} \\
(0.245)\end{array}$ \\
\hline Fed MBS Purchase Share Taper & & & $\begin{array}{c}0.172 * * \\
(0.067)\end{array}$ & $\begin{array}{c}0.103 \\
(0.207)\end{array}$ \\
\hline Agency MREIT*Fed MBS Purchase Share QE1 & & & & $\begin{array}{l}-0.185 \\
(0.264)\end{array}$ \\
\hline Agency MREIT*QE2 & & & & $\begin{array}{c}0.103 \\
(0.115)\end{array}$ \\
\hline Agency MREIT*Fed MBS Purchase Share QE3 & & & & $\begin{array}{l}-0.317 \\
(0.267)\end{array}$ \\
\hline Agency MREIT*Fed MBS Purchase Share Taper & & & & $\begin{array}{c}0.102 \\
(0.239)\end{array}$ \\
\hline Constant & $\begin{array}{c}0.682 \\
(0.698)\end{array}$ & $\begin{array}{c}0.679 \\
(0.718)\end{array}$ & $\begin{array}{c}0.581 \\
(0.677)\end{array}$ & $\begin{array}{c}0.558 \\
(0.685)\end{array}$ \\
\hline Observations & 485 & 485 & 485 & 485 \\
\hline R-squared & 0.515 & 0.515 & 0.529 & 0.536 \\
\hline Number of Firm Clusters & 26 & 26 & 26 & 26 \\
\hline
\end{tabular}




\section{Table 11: Agency MREIT Hedging}

The table presents the panel regression results for Agency MREIT interest rate derivatives (measured as swaps and swaptions to total repo debt ratio), as a function of macroeconomic factors (level and slope of the term structure, option-adjusted mortgage spread, credit spread, growth in the Case-Shiller House Price index), firm and capital structure characteristics, as well as Federal Reserve purchase shares of Treasury Securities and Agency MBS. The study period is 2005-2015. All estimates are produced using OLS. Robust standard errors (clustered by firm) are reported in parentheses. Significance is indicated as follows: *** $\mathrm{p}<0.01 ; * * \mathrm{p}<0.05 ; * \mathrm{p}<0.1$.

\begin{tabular}{|c|c|c|c|c|}
\hline VARIABLES & $\begin{array}{c}(1) \\
\text { Swaps and } \\
\text { Swaptions/Total } \\
\text { Liabilities }\end{array}$ & $\begin{array}{c}(2) \\
\text { Swaps and } \\
\text { Swaptions/Total } \\
\text { Liabilities }\end{array}$ & $\begin{array}{c}(3) \\
\text { Swaps and } \\
\text { Swaptions/Total } \\
\text { Liabilities }\end{array}$ & $\begin{array}{c}\text { (4) } \\
\text { Swaps and } \\
\text { Swaptions/Total } \\
\text { Liabilities }\end{array}$ \\
\hline 3-Month CMT & $\begin{array}{l}-0.007 \\
(0.030)\end{array}$ & $\begin{array}{l}-0.016 \\
(0.028)\end{array}$ & $\begin{array}{c}0.009 \\
(0.027)\end{array}$ & $\begin{array}{c}0.004 \\
(0.025)\end{array}$ \\
\hline CMT Term Structure & $\begin{array}{c}0.009 \\
(0.028)\end{array}$ & $\begin{array}{c}0.007 \\
(0.028)\end{array}$ & $\begin{array}{c}0.023 \\
(0.023)\end{array}$ & $\begin{array}{c}0.021 \\
(0.024)\end{array}$ \\
\hline Option-Adjusted Spread & $\begin{array}{c}0.044 \\
(0.043)\end{array}$ & $\begin{array}{c}0.038 \\
(0.040)\end{array}$ & $\begin{array}{c}0.026 \\
(0.037)\end{array}$ & $\begin{array}{c}0.025 \\
(0.036)\end{array}$ \\
\hline Credit Spread & $\begin{array}{c}-0.033^{* *} \\
(0.016)\end{array}$ & $\begin{array}{c}-0.032^{*} \\
(0.018)\end{array}$ & $\begin{array}{l}-0.018 \\
(0.014)\end{array}$ & $\begin{array}{l}-0.017 \\
(0.015)\end{array}$ \\
\hline Case-Shiller Index & $\begin{array}{l}-0.425 \\
(0.460)\end{array}$ & $\begin{array}{l}-0.529 \\
(0.464)\end{array}$ & $\begin{array}{l}-0.246 \\
(0.401)\end{array}$ & $\begin{array}{l}-0.298 \\
(0.395)\end{array}$ \\
\hline L.Equity/Assets & $\begin{array}{c}-0.231 \\
(0.267)\end{array}$ & $\begin{array}{l}-0.133 \\
(0.228)\end{array}$ & $\begin{array}{l}-0.243 \\
(0.267)\end{array}$ & $\begin{array}{l}-0.148 \\
(0.240)\end{array}$ \\
\hline L.Repo (0-30)/Repo & $\begin{array}{c}-0.197 * * * \\
(0.068)\end{array}$ & $\begin{array}{c}-0.166^{* *} \\
(0.065)\end{array}$ & $\begin{array}{c}-0.198 * * * \\
(0.069)\end{array}$ & $\begin{array}{c}-0.180^{* * *} \\
(0.063)\end{array}$ \\
\hline L.Cash/Assets & $\begin{array}{c}3.606^{* * *} \\
(0.932)\end{array}$ & $\begin{array}{c}3.400^{* * *} \\
(0.843)\end{array}$ & $\begin{array}{c}3.520^{* * *} \\
(0.932)\end{array}$ & $\begin{array}{c}3.445^{* * *} \\
(0.826)\end{array}$ \\
\hline L.Firm Size & $\begin{array}{c}0.038 \\
(0.028)\end{array}$ & $\begin{array}{c}0.036 \\
(0.028)\end{array}$ & $\begin{array}{c}0.036 \\
(0.028)\end{array}$ & $\begin{array}{c}0.036 \\
(0.028)\end{array}$ \\
\hline L.Fixed-Rate/Total Agency Securities & $\begin{array}{c}0.176^{* *} \\
(0.077)\end{array}$ & $\begin{array}{c}0.178^{* *} \\
(0.074)\end{array}$ & $\begin{array}{c}0.163^{* *} \\
(0.077)\end{array}$ & $\begin{array}{c}0.163 * * \\
(0.075)\end{array}$ \\
\hline Agency MREIT & $\begin{array}{c}0.205^{* * *} \\
(0.055)\end{array}$ & $\begin{array}{c}0.100 \\
(0.061)\end{array}$ & $\begin{array}{c}0.210^{* * *} \\
(0.058)\end{array}$ & $\begin{array}{c}0.148^{* * *} \\
(0.052)\end{array}$ \\
\hline Fed Treasury Purchase Share & $\begin{array}{c}0.012 \\
(0.179)\end{array}$ & $\begin{array}{c}0.034 \\
(0.173)\end{array}$ & $\begin{array}{l}-0.148 \\
(0.248)\end{array}$ & $\begin{array}{l}-0.133 \\
(0.240)\end{array}$ \\
\hline Fed MBS Purchase Share & $\begin{array}{c}0.094 \\
(0.074)\end{array}$ & $\begin{array}{c}-0.215^{*} \\
(0.125)\end{array}$ & & \\
\hline Agency MREIT*Fed MBS Purchase Share & & $\begin{array}{c}0.426^{* * *} \\
(0.142)\end{array}$ & & \\
\hline Fed MBS Purchase Share QE1 & & & $\begin{array}{l}-0.029 \\
(0.048)\end{array}$ & $\begin{array}{l}-0.030 \\
(0.066)\end{array}$ \\
\hline QE2 & & & $\begin{array}{c}0.024 \\
(0.045)\end{array}$ & $\begin{array}{l}-0.074 \\
(0.078)\end{array}$ \\
\hline Fed MBS Purchase Share QE3 & & & $\begin{array}{l}0.171 * \\
(0.085)\end{array}$ & $\begin{array}{l}-0.020 \\
(0.183)\end{array}$ \\
\hline Fed MBS Purchase Share Taper & & & $\begin{array}{c}0.096 \\
(0.071)\end{array}$ & $\begin{array}{c}-0.302^{* * *} \\
(0.079)\end{array}$ \\
\hline Agency MREIT*Fed MBS Purchase Share QE1 & & & & $\begin{array}{l}-0.001 \\
(0.096)\end{array}$ \\
\hline Agency MREIT*QE2 & & & & $\begin{array}{c}0.126 \\
(0.090)\end{array}$ \\
\hline Agency MREIT*Fed MBS Purchase Share QE3 & & & & $\begin{array}{c}0.255 \\
(0.218)\end{array}$ \\
\hline Agency MREIT*Fed MBS Purchase Share Taper & & & & $\begin{array}{c}0.556^{* * *} \\
(0.113)\end{array}$ \\
\hline Constant & $\begin{array}{l}-0.353 \\
(0.485)\end{array}$ & $\begin{array}{l}-0.278 \\
(0.488)\end{array}$ & $\begin{array}{l}-0.382 \\
(0.473)\end{array}$ & $\begin{array}{l}-0.350 \\
(0.473)\end{array}$ \\
\hline Observations & 474 & 474 & 474 & 474 \\
\hline R-squared & 0.526 & 0.551 & 0.533 & 0.560 \\
\hline Number of Firm Clusters & 25 & 25 & 25 & 25 \\
\hline
\end{tabular}

